\title{
Cryoturbation leads to iron-organic carbon associations along a permafrost soil chronosequence in northern Alaska
}

\author{
Hanna Joss', Monique S. Patzner', Markus Maisch', Carsten W. Mueller², Andreas \\ Kappler $^{1,3}$, Casey Bryce ${ }^{4 *}$ \\ ${ }^{1}$ Geomicrobiology, Center for Applied Geoscience, University of Tübingen, Germany \\ ${ }^{2}$ Department of Geosciences and Natural Resource Management, University of Copenhagen, \\ Denmark \\ ${ }^{3}$ Cluster of Excellence: EXC 2124: Controlling Microbes to Fight Infection, Tübingen, Germany \\ ${ }^{4}$ School of Earth Sciences, University of Bristol, UK \\ Corresponding author: Casey Bryce (casey.bryce@ bristol.ac.uk) \\ *School of Earth Sciences, Wills Memorial Building, Queens Road, Bristol BS8 1RJ
}

\section{Key Points}

- Percentage of iron-associated organic carbon highest in cryoturbated horizons compared to organic or mineral horizons

- Increase in iron-associated organic carbon stocks present after 50 years of soil development due to enhanced cryoturbation

- Close spatial association of organic carbon and iron minerals, likely ferrihydrite, as shown by nanoscale- and spectroscopic analysis 


\begin{abstract}
In permafrost soils, substantial amounts of organic carbon (OC) are potentially protected from microbial degradation and transformation into greenhouse gases by association with reactive iron $(\mathrm{Fe})$ minerals. As permafrost environments respond to climate change, increased drainage of thaw lakes in permafrost regions is predicted. Soils will subsequently develop on these drained thaw lakes, but the role of Fe-OC associations in future OC stabilization during this predicted soil development is unknown. To fill this knowledge gap, we have examined Fe-OC associations in organic, cryoturbated and mineral horizons along a 5500-year chronosequence of drained thaw lake basins in Utqiagivik, Alaska. By applying chemical extractions, we found that $\sim 17 \%$ of the total OC content in cryoturbated horizons is associated with reactive Fe minerals, compared to $\sim 10 \%$ in organic or mineral horizons. As soil development advances, the total stocks of Fe-associated OC more than double within the first 50 years after thaw lake drainage, because of increased storage of Fe-associated OC in cryoturbated horizons (from 8 to $75 \%$ of the total Feassociated OC stock). Spatially-resolved nanoscale secondary ion mass spectrometry showed that OC is primarily associated with Fe(III) (oxyhydr)oxides which were identified by ${ }^{57} \mathrm{Fe}$ Mössbauer spectroscopy as ferrihydrite. High OC:Fe mass ratios (>0.22) indicate that Fe-OC associations are formed via co-precipitation, chelation and aggregation. These results demonstrate that, given the proposed enhanced drainage of thaw lakes under climate change, OC is increasingly incorporated and stabilized by the association with reactive Fe minerals as a result of soil formation and increased cryoturbation.
\end{abstract}

\title{
1 Introduction
}

Increasing soil temperatures induced by climate change are accelerating permafrost thaw. Since permafrost soils store approximately $1035 \pm 150 \mathrm{Pg}$ organic carbon (OC) in the upper $3 \mathrm{~m}$ (Hugelius et al., 2014), rapid warming could potentially unlock vast amounts of OC and stimulate release of greenhouse gases to the atmosphere. Thermokarst landscapes are assumed to be most vulnerable to abrupt changes in a warming climate (Turetsky et al., 2020; Walter Anthony et al., 2018). They cover around $20 \%$ of the northern permafrost region and are estimated to store around $30 \%$ of the total OC (TOC) present in the upper $3 \mathrm{~m}$ of the circumpolar permafrost region (Olefeldt et al., 2016). As in other arctic lowland regions, thermokarst lakes are the dominating landscape feature of northern Alaska and follow a general thaw lake cycle (Grosse et al., 2013; Hinkel et al., 
2003). Lakes form by thermokarst processes and drain due to e.g. ice-wedge or coastal erosion. After drainage, terrestrial soils develop in the drained thermokarst lake basins on the remaining sediments and ice-wedge growth continues which potentially reforms lakes. It is assumed that the reformation of thaw lakes will be absent in the future, due to insufficient ice wedge growth (Fuchs et al., 2019) which disrupts the thaw lake cycle and promotes the ongoing soil development on drained thaw lake basins. The soils developing on these thermokarst lake basins are increasingly influenced by cryoturbation which redistributes relatively young OC from the topsoil into deeper soil layers and contributes on average $55 \%$ to the soil OC density in the active layer and the nearpermafrost surface in permafrost soils from Alaska (Bockheim, 2007).

Previous studies on permafrost soils have intensively focused on the decomposition of the stored OC (Estop-Aragones et al., 2020; Hopple et al., 2020; Schädel et al., 2016), whereas only a few have focused on the stabilization mechanisms of OC which can mitigate the permafrost carbon feedback (Mu et al., 2016; Mu et al., 2020; Mueller et al., 2017; Osterkamp \& Romanovsky, 1999; Patzner et al., 2020; Prater et al., 2020; Schuur et al., 2015; Wang et al., 2020). In soils, the fate of OC is determined by an interplay of various physical, chemical and biological components (Lehmann et al., 2020). The accessibility of OC for microorganisms is reduced by physical protection within soil aggregates and by interactions with minerals that stabilize OC via sorption, co-precipitation or aggregation (Hemingway et al., 2019; Kaiser \& Guggenberger, 2000; KögelKnabner et al., 2008; von Lützow et al., 2008; Wagai \& Mayer, 2007).

Reactive iron (Fe) minerals (defined as those reductively dissolvable by sodium dithionite e.g. Fe(III) (oxyhydr)oxides) are particularly important for the stabilization of OC in various environments (Coward et al., 2017; Lalonde et al., 2012; Shields et al., 2016; Zhao et al., 2016), whereas Fe-OC associations in organic rich soils of high latitude regions are less well studied. Recent studies point towards a significant proportion of reactive Fe associated OC in permafrost soils (Herndon et al., 2017; Mu et al., 2016; Mu et al., 2020; Patzner et al., 2020; Sowers et al., 2020). In the permafrost soil chronosequence of drained thaw lake basins in northern Alaska we have studied, Mueller et al.(2015) found the oldest OC fraction directly associated with minerals, especially with Fe (oxyhydr)oxides (Mueller et al., 2017; Mueller, Steffens and Buddenbaum, 2020). This highlights the potential of reactive Fe minerals in the stabilization of OC over thousands of years in thermokarst regions (Kögel-Knabner et al., 2008; Mueller et al., 2015). 
Despite the recognized role of reactive $\mathrm{Fe}$ minerals in the association with $\mathrm{OC}$ in permafrost soils, very little is known about the long-term development of Fe-OC associations especially in thermokarst regions. In order to address this knowledge gap, we quantified Fe-OC associations of soil cores from drained thaw lake basins spanning 5500 years of soil development by using selective chemical extractions. We further identified the reactive Fe minerals involved in the association with $\mathrm{OC}$ in different soil horizons and soil development stages along the

chronosequence with ${ }^{57} \mathrm{Fe}$-specific Mössbauer spectroscopy. This was complemented by visually highlighting spatial Fe-OC associations in soil horizons using correlative scanning electron microscopy and nanoscale secondary ion mass spectrometry. This approach allows us to evaluate biogeochemical drivers of Fe-OC associations along the soil profile and during progressive soil development after thaw lake drainage.

\section{Materials and Methods}

\subsection{Sampling and soil properties}

Permafrost soil cores along a chronosequence of drained thaw lake basins near Utqiagivik in northern Alaska were collected in April 2010 during the sampling campaign described in Mueller et al. (2015). Based on vegetation succession and ${ }^{14} \mathrm{C}$ data, the soil chronosequence is classified into distinct age classes covering young (0-50 years), medium (50-300 years), old (3002000 years) and ancient (2000-5500 years) drained basins (Hinkel et al., 2003). Briefly, four soil cores of each age class were collected using an 80-150 cm long corer from the Snow, Ice, Permafrost Research Establishment (SIPRE) with $7.5 \mathrm{~cm}$ diameter attached to a Big Beaver earth drill apparatus (Little Beaver, US). Samples were transported within $8 \mathrm{~h}$ to a cold room in Utqiagvik where soil description followed. The frozen cores were cut with a chop saw into corresponding soil horizons and subsamples were oven-dried at $60^{\circ} \mathrm{C}$ for further analysis. Within our study, two soil cores of each age class were analyzed from locations spanning from $71^{\circ} 12^{\prime}$ to $71^{\circ} 16^{\prime} \mathrm{N}$ in latitude and $156^{\circ} 25^{\prime}$ to $156^{\circ} 39^{\prime} \mathrm{W}$ longitude (Figure SI 1). These soil cores were selected based on the core depth and on soil horizons to capture soil profiles representative for the individual age classes (informed by Mueller et al. (2015)). The selected soil cores along the chronosequence differ in maximum core length (sampled soil depth) ranging from 90 to $126 \mathrm{~cm}$ and reach the permafrost layer at around 30 to $50 \mathrm{~cm}$ depth (Figure 1). Soil cores of the young age class show little to no cryoturbation and are mainly dominated by one organic horizon followed 
by mineral horizons. The abundance of soil horizons with indications of cryoturbated soil material increases with the age of the drained thaw lake basins. Buried horizons are combined with, and referred to as, cryoturbated horizons in the following discussion as they both lead to a redistribution of organic material into deeper soil layers.

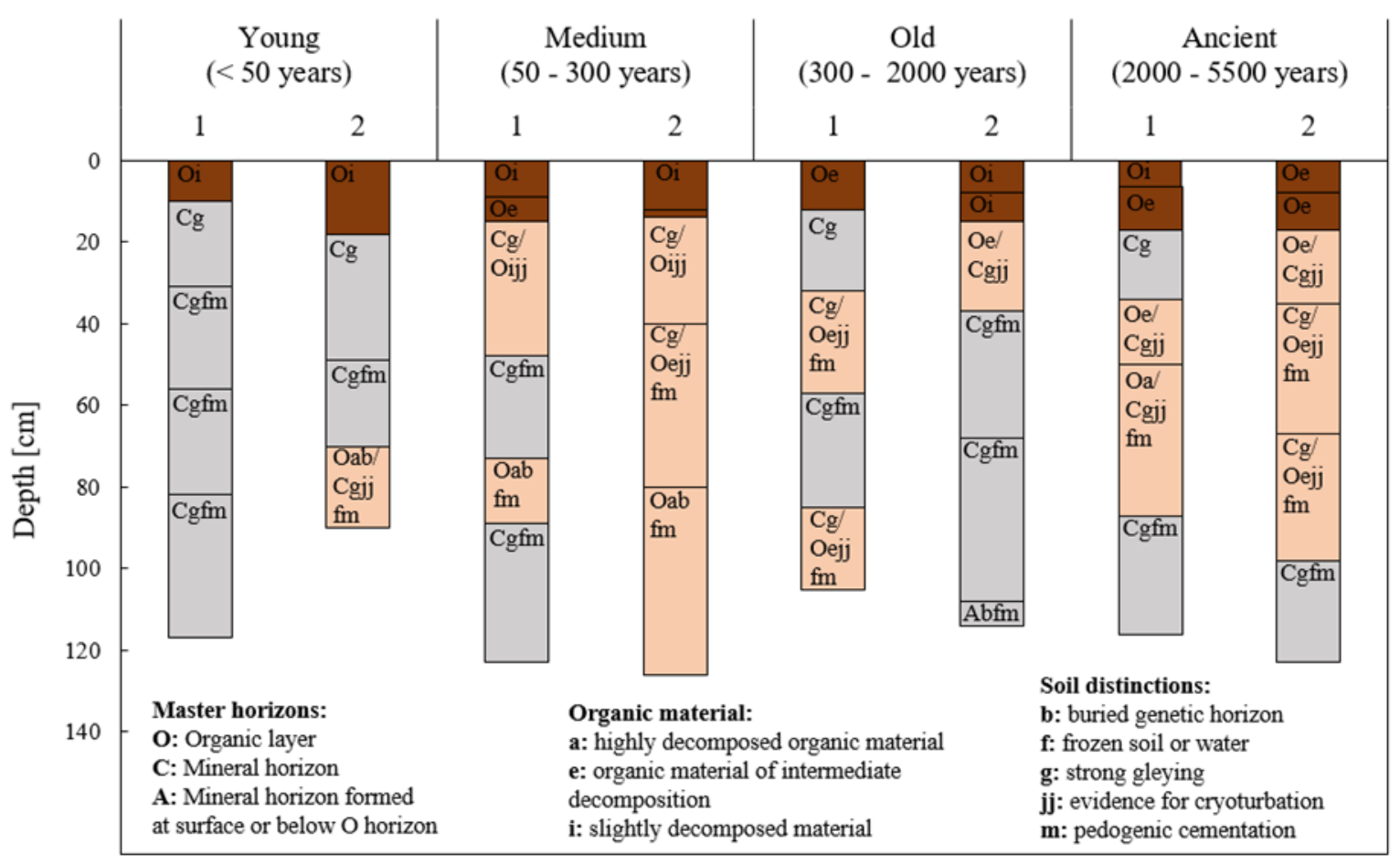

Figure 1 | Classification according to Mueller et al. (2015) and description of soil horizons of replicate soil cores of the four different age classes. Abbreviations assigned to the distinct soil horizons are described below the figure. Colors indicate organic horizons (brown), cryoturbated/buried horizons (beige) and mineral horizons (grey).

\subsection{Selective extractions}

Soil horizons of two soil cores representative of each age class were selectively extracted to quantify different Fe mineral phases and the associated OC (Cornell \& Giovanoli, 1988; Mehra \& Jackson, 1960). To prepare for the chemical extractions, glass vials were washed with $1 \mathrm{M} \mathrm{HCl}$, rinsed with deionized water and sterilized for $4.5 \mathrm{~h}$ at $180^{\circ} \mathrm{C}$. Oven-dried soil samples $(0.15 \pm 0.05 \mathrm{~g})$ were weighed into glass vials in duplicates and degassed with $\mathrm{N}_{2}$ prior to extraction. To target poorly crystalline and crystalline Fe(III) (oxyhydr)oxides (in the following considered as the total extractable Fe), samples were extracted anoxically in the dark over $24 \mathrm{~h}$ at $70^{\circ} \mathrm{C}$ with 
$3.125 \mathrm{~mL}$ of a $6 \mathrm{M} \mathrm{HCl}$ solution (Foucher et al., 2000; Pehkonen, 1995; Peltier et al., 2005; Porsch \& Kappler, 2011; Rutledge et al., 2010).

In parallel, a dithionite-citrate bicarbonate extraction was carried out to selectively extract reactive Fe minerals (defined here as reductively dissolvable by dithionite-citrate extraction) such as ferrihydrite, goethite, lepidocrocite, akaganeite and hematite nanoparticles (Cornell \& Schwertmann, 2003; Coward et al., 2017; Mehra \& Jackson, 1960; Raiswell et al., 1994). This extraction also allows for the quantification of OC that is mobilized during the reductive dissolution of reactive Fe minerals (in the following referred to as Fe-associated OC) (Lalonde et al., 2012; Mu et al., 2016; Mu et al., 2020; Patzner et al., 2020). We followed the dithionite-citrate extraction which is performed for $16 \mathrm{~h}$ on a rolling shaker under room temperature and anoxically in the dark (Coward et al., 2017; Wagai et al., 2013; Wagai \& Mayer, 2007) and combined different approaches to account for potential difficulties when using this extraction method as previously discussed in detail by Patzner et al. (2020) and shortly discussed in the following. Due to the instability of dithionite in solution (Varadachari et al., 2006), powdered dithionite was added to the sample to reach a final concentration of $0.1 \mathrm{M}$ by adding $3.125 \mathrm{~mL}$ of a $0.27 \mathrm{M}$ trisodium citrate, $0.11 \mathrm{M}$ sodium bicarbonate solution ( $\mathrm{pH} 7, \mathrm{~N}_{2}: \mathrm{CO}_{2}(90: 10, \mathrm{v}: \mathrm{v})$ headspace). Sodium bicarbonate was used as a buffer $(\mathrm{pH} 7)$ to prevent hydrolysis and re-sorption of organic matter under acidic pH. Fisher et al. (2020) showed that under neutral pH, the dithionite-citrate extraction only partially dissolves reactive Fe minerals, thus leading to an underestimation of the amount of reactive Fe minerals in the analyzed soil cores. Trisodium citrate was used as a complexing agent to prevent re-precipitation of the mobilized Fe and sorption of OC (Mehra \& Jackson, 1960). A pre-test carried out under the same conditions ( $\mathrm{pH}$, ionic strength) showed that without citrate, $43.5 \pm 17.6 \%$ less reactive $\mathrm{Fe}$ and $37.2 \pm 4.4 \%$ less reactive Fe-associated $\mathrm{OC}$ was obtained in an organic horizon of a medium aged soil core (Table SI 1). To account for effects of soil drying on reactive Fe minerals and Fe-associated $\mathrm{OC}$, comparable permafrost soil material from a desiccating palsa in northern Sweden (Patzner et al., 2020) was dried under anoxic and oxic conditions at room temperature and $60^{\circ} \mathrm{C}$. We obtained similar reactive $\mathrm{Fe}$ and $\mathrm{Fe}$-associated $\mathrm{OC}$ contents by the dithionite-citrate extraction method for all drying techniques (Table SI 2).

To also account for the OC which is readily desorbed from the sample and not directly associated with reactive Fe minerals, a $1.85 \mathrm{M}$ sodium chloride $(\mathrm{NaCl}), 0.11 \mathrm{M}$ sodium bicarbonate

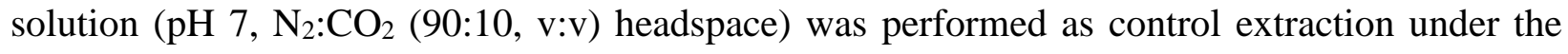


same conditions as the dithionite-citrate extraction (Table SI 3) (Lalonde et al., 2012; Patzner et al., 2020). It has to be noted that the $\mathrm{NaCl}$ control extraction was shown to also extract $\mathrm{OC}$ that was weakly bound to reactive Fe minerals (Fisher et al., 2020). As the OC quantified by the $\mathrm{NaCl}$ control extraction is subtracted from the OC mobilized by the dithionite-citrate extraction, the amount of Fe-associated OC is likely underestimated.

\subsection{Geochemical analyses}

The supernatant from the selective extractions was obtained by centrifugation (10 min, $13400 \mathrm{rpm})$ and subsequently analyzed for total $\mathrm{Fe}(6 \mathrm{M} \mathrm{HCl}$ extractable) and reactive $\mathrm{Fe}$ (dithionite-citrate extractable) using the ferrozine assay (Stookey, 1970) following the protocol from Hegler et al. (2008). Briefly, to quantify total Fe, $80 \mu \mathrm{L}$ of hydroxylamine-HCl were incubated for 30 min with $20 \mu \mathrm{L}$ of the supernatant which was diluted in $1 \mathrm{M} \mathrm{HCl}$ beforehand. The dilution of samples ensured that the initial brownish color of the supernatant, resulting from OC, did not interfere with the spectrophotometric quantification. $100 \mu \mathrm{L}$ of ferrozine was then added, the solution was mixed and incubated for $5 \mathrm{~min}$ to allow for the spectrophotometric quantification at $562 \mathrm{~nm}$. Subsequently, reactive Fe contents were calculated by subtracting the Fe readily mobilized during the $\mathrm{NaCl}$ control extraction.

OC in the supernatant of the selective extractions and in the trisodium citrate-bicarbonate solution (citrate background) was analyzed by combustion at $750^{\circ} \mathrm{C}$ (Elemental analyzer, multi N/C 2100S, Analytik Jena GmbH, Germany). The Fe-associated OC was calculated by subtracting the $\mathrm{OC}$ background from the trisodium citrate-bicarbonate solution and the $\mathrm{NaCl}$ control extraction. As a consequence of the high OC background imposed by the use of citrate, $\mathrm{Fe}-$ associated OC could not be quantified in four soil horizons (young 1: 56-82 and 82-117 cm, ancient 1: $87-116 \mathrm{~cm}$ and ancient 2: $34-50 \mathrm{~cm}$ ), however the amount of Fe-associated OC was typically high and detectable in most samples.

The TOC content of horizons in soil cores from drained thaw lake basins was previously analyzed in the study of Mueller et al. (2015). Briefly, sample material was ground with a ball mill and measured in duplicates via dry combustion (Vario MAX CNS Analyzer, Elementar, Hanau, Germany). The measured carbon contents represent the TOC content due to absence of carbonates. 
Stocks of reactive Fe and associated OC (Eq. 1) were calculated based on content, bulk density (BD) and layer thickness of the horizons in each soil core (Table SI 3).

$$
\text { Stock }\left[\mathrm{kg} \mathrm{m}^{-2}\right]=\text { content }\left[\mathrm{mg} \mathrm{g}^{-1}\right] \cdot \mathrm{BD}\left[\mathrm{g} \mathrm{cm}^{-3}\right] \cdot \text { layer thickness }[\mathrm{m}]
$$

To account for differences along the permafrost soil chronosequence, reactive $\mathrm{Fe}$ and associated OC stock of same horizons (organic, cryoturbated or mineral) within one soil core were summed up and averaged between replicate soil cores of one age class to represent the average total sum present in distinct soil horizons within one age class.

\subsection{Fe mineralogy and spectroscopic analysis}

To identify the mineralogy of the reactive Fe minerals potentially involved in the association with OC, ${ }^{57} \mathrm{Fe}$-specific Mössbauer spectroscopy was applied. Prior to Mössbauer analysis, dried sample material from organic, cryoturbated and mineral horizons of two endmember soil cores (young, ancient) was mortared and loaded into plexiglass holders $\left(1 \mathrm{~cm}^{2}\right)$, forming a thin film of sample material. Plexiglass holders were tightly closed with parafilm and transmission spectra were collected at $77 \mathrm{~K}$ and $5 \mathrm{~K}$ using a constant acceleration drive system (WissEL) in transmission mode with a ${ }^{57} \mathrm{Co} / \mathrm{Rh}$ source. All spectra were calibrated against a $7 \mu \mathrm{m}$ thick $\alpha-{ }^{57} \mathrm{Fe}$ foil that was measured at $295 \mathrm{~K}$. Sample analysis was carried out using Recoil (University of Ottawa) and the Voigt Based Fitting (VBF) routine (Rancourt \& Ping, 1991). The half width at half maximum was constrained to $0.124 \mathrm{~mm} \mathrm{~s}^{-1}$ during fitting.

For visualizing Fe-OC associations with correlative scanning electron microscopy (SEM) and nanoscale secondary ion mass spectrometry (NanoSIMS) analysis, the deepest horizon of an intact frozen soil core (medium 2, Figure 1) was chemically fixed, dried over an acetone row and subsequently impregnated with Araldite 502 (Araldite kit 502, electron microscope sciences, Hatfield, USA). The impregnated soil core was sectioned and polished (see details in Mueller et al. (2017)). Prior to SEM analysis (Jeol JSM 5900LV, Freising, Germany) in backscatter electron mode and NanoSIMS analysis, the intact cross section was gold-coated by physical vapor deposition under argon atmosphere to circumvent possible charging effects. The NanoSIMS measurements were recorded at the Cameca NanoSIMS $50 \mathrm{~L}$ (Gennevilliers, France) of the Lehrstuhl für Bodenkunde, TU München, Germany. Electron multiplier secondary ion collectors 
were used for ${ }^{12} \mathrm{C}^{14} \mathrm{~N}^{-},{ }^{27} \mathrm{Al}^{16} \mathrm{O}^{-}$and ${ }^{56} \mathrm{Fe}^{16} \mathrm{O}^{-}$. Prior to analysis, impurities and the coating layer were sputtered away by using a high primary beam current and charging during the measurements was compensated by an electron beam generated by the electron flood gun of the NanoSIMS instrument (Mueller et al., 2013). The NanoSIMS data was analyzed using the Look@NanoSIMS plugin for MatLab (Polerecky et al., 2012), images were corrected for detector dead time and drift corrected.

\subsection{Statistical analysis}

An analysis of variance (ANOVA) was applied using RStudio (Version 1.3.959) to identify differences between soil age classes, combined with a post-hoc test to identify age classes that are different from another. Whenever normal distribution or homogeneity of variances was not given, a non-parametric Kruskal Wallis test was performed. For correlation analysis of non-normally distributed data, $\mathrm{p}$-values ( $\mathrm{p}$ ) and correlation coefficients ( $\mathrm{r}$ ) are given for a Spearman $\left(\mathrm{p}_{\mathrm{s}}\right.$ and $\left.\mathrm{r}_{\mathrm{s}}\right)$ correlation. Additionally, linear regressions $\left(\mathrm{R}^{2}\right)$ were calculated to identify relationships between reactive $\mathrm{Fe}$ and associated $\mathrm{OC}$ across age classes.

\section{Results and Discussion}

3.1 Changes in reactive $\mathrm{Fe}$ and associated $\mathrm{OC}$ along the soil chronosequence

3.1.1 Greater differences in reactive Fe and associated OC between soil horizons than with depth

Contents of reactive Fe and associated OC did not show a clear trend with depth, but were significantly different between soil horizons across the soil profiles ( $p<0.001$, Kruskall Wallis test) (Figure 2, Figure 3). Reactive Fe contents were highest in organic horizons (10 to $60 \mathrm{mg} \mathrm{g}^{-1}$ DW-soil ${ }^{-1}$ ) with a significantly higher content compared to cryoturbated ( $\mathrm{p}<0.001,5$ to $20 \mathrm{mg} \mathrm{g}^{-1}$ DW-soil ${ }^{-1}$ ) and mineral horizons ( $<<0.001,2$ to $20 \mathrm{mg} \mathrm{g}^{-1} \mathrm{DW}$-soil ${ }^{-1}$ ) (Figure 2, Figure 3). Cryoturbated horizons incorporate, in comparison to directly over- or underlying mineral horizons, higher amounts of reactive Fe (Figure 2), even though overall differences in reactive Fe between cryoturbated and mineral horizons were not significant.

Horizons with elevated contents of reactive Fe in comparison to over- or underlying horizons were also identified to overlay the permafrost table (Figure 1), subject to annual 
freeze/thaw cycles that experience fluctuations in redox conditions. At such redox interfaces, $\mathrm{Fe}(\mathrm{III})$ (oxyhydr)oxides are assumed to be effectively recycled forming poorly crystalline $\mathrm{Fe}$ minerals (Moormann \& van Breemen, 1978) which counteracts the crystallization of reactive $\mathrm{Fe}$ minerals with time. Even though Chen et al. (2020) postulated the formation of more crystalline Fe minerals under redox fluctuations due to oxygen limitation, the association with high amounts of OC, as found in affected soil horizons, impede the crystallization of reactive Fe minerals (Schwertmann, 1966). Additionally, Fe(II) which is reduced in deeper, anoxic soil layers migrates upwards and subsequently is oxidized by oxygen and precipitates as $\mathrm{Fe}$ (III) (oxyhydr)oxides (Herndon et al., 2015; Liang et al., 1993). This likely explains highest contents and percentages (as \% of total $\mathrm{Fe}$ ) of reactive $\mathrm{Fe}$ found in organic horizons in our soil cores ( $\sim 100 \%$ reactive $\mathrm{Fe}$ of the total Fe, Figure SI 2). In accordance to other studies from the same region, we also find highest amounts of poorly crystalline Fe minerals (represented here as reactive Fe) in organic horizons (Herndon et al., 2017) and overall higher amounts of reactive Fe compared to other permafrost regions (Mu et al., 2016; Patzner et al., 2020).

Fe-associated OC contents were also highest in organic horizons (20 to $80 \mathrm{mg} \mathrm{g}^{-1}$ DW-soil $\left.{ }^{-1}\right)$ and are significantly different from cryoturbated ( $<<0.001,0$ to $40 \mathrm{mg} \mathrm{g}^{-1} \mathrm{DW}$-soil $\left.{ }^{-1}\right)$ and mineral horizons ( $\mathrm{p}<0.001,0$ to $25 \mathrm{mg} \mathrm{g}^{-1} \mathrm{DW}$-soil ${ }^{-1}$ ) (Figure 2, Figure 3). It has to be noted that TOC contents were also greatest in organic horizons (Figure SI 2). In deeper soil layers, significantly elevated contents of Fe-associated OC were found in cryoturbated horizons in comparison to mineral horizons $(\mathrm{p}=0.025)$. This can be explained by the introduction of OC into deeper soil layers by cryoturbation (Figure SI 2).

Cryoturbation redistributes mostly young, undecomposed OC into deeper soil layers (Ping et al., 1998), as was also shown by ${ }^{14} \mathrm{C}$ analysis for the same permafrost soil samples (Mueller et al., 2015). The relocated OC in cryoturbated horizons was furthermore characterized to be more bioavailable compared to over- or underlying mineral horizons as indicated by $\mathrm{O}-\mathrm{N} / \mathrm{alkyl} \mathrm{C}$ to alkyl C ratios obtained by NMR spectroscopy (Mueller et al., 2015). Thus, it can be assumed that easily available $\mathrm{OC}$ is associated with reactive Fe minerals as the Fe-associated OC constitutes a large proportion of the TOC in cryoturbated horizons. Also, similar amounts of Fe-associated OC are present in other permafrost regions (Mu et al., 2016; Patzner et al., 2020), although Feassociated $\mathrm{OC}$ contents could be underestimated as a result of the $\mathrm{NaCl}$ control extraction (Fisher et al., 2020). 


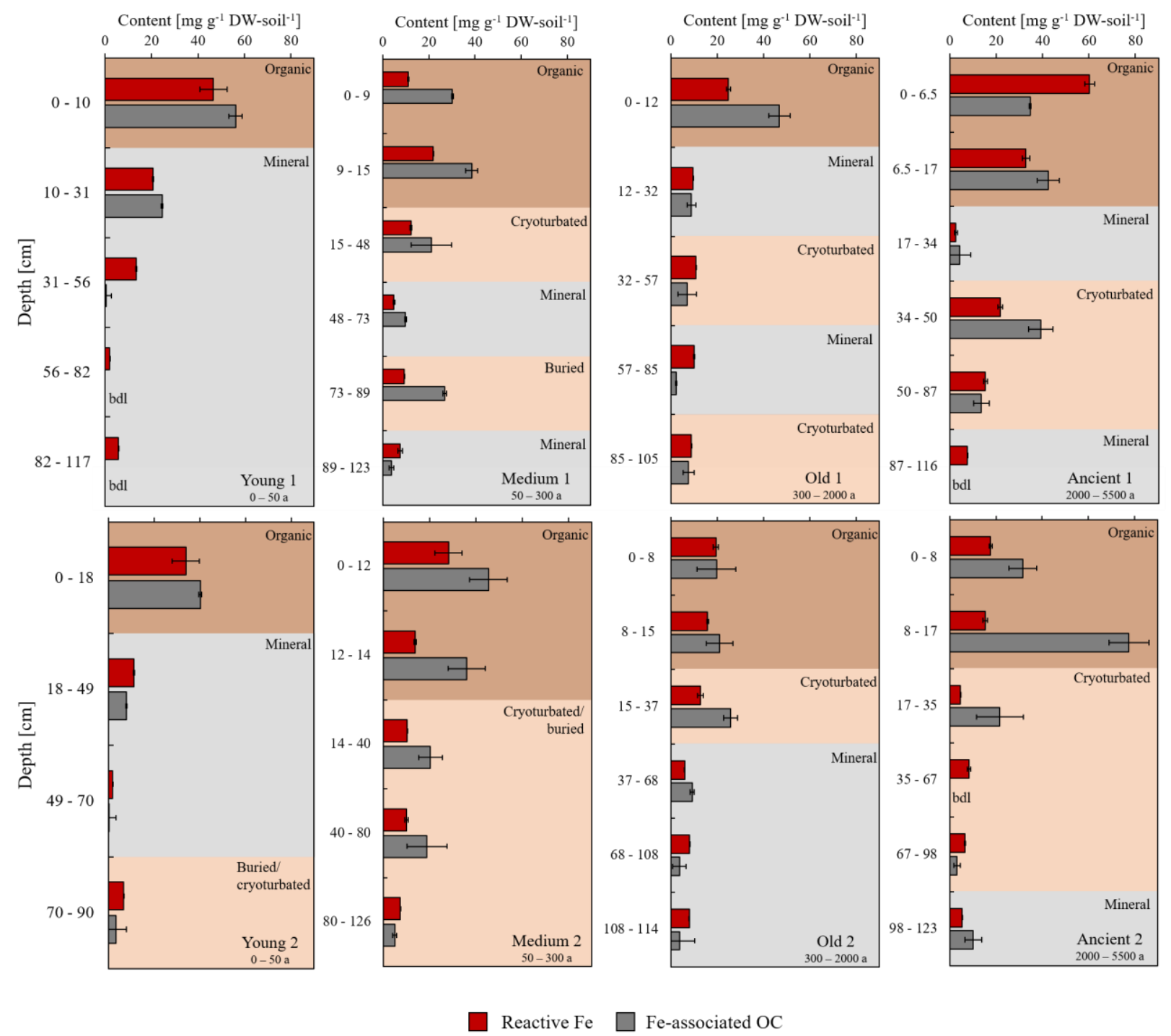

Figure $2 \mid$ Soil horizons determine the content of reactive Fe (red) and Fe-associated OC (grey) along the soil profile of replicate cores $(1,2)$ from four age classes (young, medium, old, ancient) of drained thaw lake basins from Alaska. Reactive Fe is dithionite-citrate extractable Fe corrected by $\mathrm{NaCl}$ control extraction and $\mathrm{Fe}$-associated $O C$ is dithionite-citrate extractable $\mathrm{OC}$ corrected by $\mathrm{NaCl}$ control extraction and citrate background, presented as $m g g^{-1} \mathrm{DW}$-soil ${ }^{-1}$. Soil horizons are highlighted by color shading (brown: organic, beige: cryoturbated/buried, grey: mineral). Error bars represent a combined range of duplicate extractions per horizon of replicate soil cores.

Generally, reactive Fe and Fe-associated OC contents over all soil horizons and age classes correlate significantly $\left(\mathrm{p}_{\mathrm{s}}<0.001, \mathrm{r}_{\mathrm{s}}=0.76\right)$ (Figure 3). By categorizing the percentage of Feassociated OC into four ranges (0-10, 10-25, 25-50, 50-100\%) (Figure 3), it can be shown that Feassociated $\mathrm{OC}$ constitutes a higher proportion of TOC in cryoturbated horizons compared to 
organic and mineral horizons. Cryoturbated horizons show mainly 10-25\% Fe-associated OC, whereas organic horizons have between 0-25\% and mineral horizons have between 0-10 \% Feassociated OC.

The depth distribution demonstrates that the content of reactive $\mathrm{Fe}$ and associated $\mathrm{OC}$ is controlled by soil horizons rather than by depth or age class and is supported by significant differences found between soil horizons.

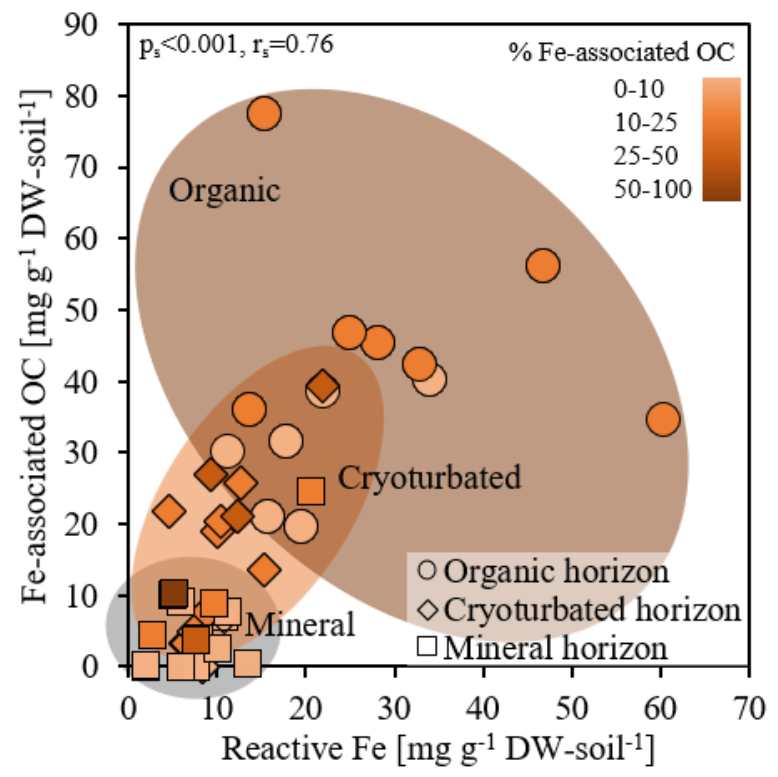

Figure 3 | Horizon-dependent correlation of reactive Fe and Fe-associated OC in organic horizons (circle, $n=13$ ), cryoturbated/buried horizons (diamond, $n=14$ ) and mineral horizons (square, $n=16$ ) of replicate cores ( 1 , 2) from four age classes (young, medium, old, ancient) of drained thaw lake basins from Alaska. Reactive Fe is dithionite-citrate extractable $\mathrm{Fe}$ corrected by $\mathrm{NaCl}$ control extraction and $\mathrm{Fe}$-associated $\mathrm{OC}$ is dithionite-citrate extractable OC corrected by $\mathrm{NaCl}$ control extraction and citrate background, presented as $\mathrm{mg} \mathrm{g}^{-1} \mathrm{DW}$-soil ${ }^{-1}$. Data points represent the average from duplicate extractions filled with a color gradient depending on the amount of Feassociated OC as percentage of TOC.

3.1.2 Reactive Fe and Fe-associated OC increasingly distributed in cryoturbated horizons with progressive soil development

In order to follow the Fe-OC associations with progressive soil development, soil horizons of replicate soil cores of four age classes were analyzed, integrated over the soil profile and averaged over the replicate cores. The relationship of reactive Fe and associated OC is increasingly 
heterogeneous along the soil chronosequence (Figure SI 3). Overall, a maximum of $73.66 \pm 5.65 \%$ of the total extractable Fe was quantified as reactive Fe and $13.68 \pm 2.31 \%$ of the TOC was found to be associated with reactive Fe minerals over the soil profiles (Table 1). In comparison to other studies focusing on Fe-OC associations in permafrost soils, we find similar amounts of OC associated with reactive Fe minerals. In permafrost soils from the Qinghai-Tibetan-Plateau, a maximum of $23.09 \pm 16.42 \%$ of the TOC is associated with reactive Fe minerals in soil cores of an alpine desert steppe (Mu et al., 2016) and a maximum of $7 \%$ in soils overlying intact permafrost in Sweden when averaged over the soil profile (Patzner et al., 2020).

Across age classes of the permafrost soil chronosequence, reactive Fe contents are relatively constant (Figure 4 a), but significant differences between age classes were found for the content of Fe-associated OC $(\mathrm{p}=0.008)$ between the young and the medium $(\mathrm{p}=0.0214,66.34 \pm 8.75$ to $128.12 \pm 18.86 \mathrm{mg} \mathrm{g}^{-1} \mathrm{DW}$-soil ${ }^{-1}$, Table 1) and the young and ancient age class $(\mathrm{p}=0.0118$, $66.34 \pm 8.75$ to $139.25 \pm 23.54 \mathrm{mg} \mathrm{g}^{-1} \mathrm{DW}$-soil ${ }^{-1}$, Table 1) (Figure 4 a). Even though the majority of reactive $\mathrm{Fe}$ and associated $\mathrm{OC}$ content is contained in organic horizons along the soil chronosequence, cryoturbated horizons incorporate 6 to 8 times more reactive Fe (from $\sim 4 \%$ in young to $24-36 \%$ in older age classes) and 10 to 14 times more associated OC (from $2 \%$ in young to 26-36 \% in older age classes) from the young to the older age classes (medium, old, ancient) (Figure 4 a). Our consistent trend in reactive Fe across soil age classes indicates either a stable pool of reactive Fe minerals over 5500 years of soil development by impeded crystallization and hydrolysis of Fe minerals by association with OC (Amstaetter et al., 2012; Cornell \& Schwertmann, 2003; Schwertmann \& Murad, 1988) or likely results from effective recycling of Fe minerals under redox fluctuations as was already observed in the same permafrost region (Herndon et al., 2017).

Stocks of reactive Fe do not significantly change $\left(6.22 \pm 0.33\right.$ to $6.40 \pm 0.34 \mathrm{~kg} \mathrm{~m}^{-2}$ from young to ancient, Figure 4 b, Table 1), but the distribution of reactive Fe in soil horizons differs along the soil chronosequence. Cryoturbated horizons store $10 \%$ of the total reactive Fe stock in the young age class and 34-72\% in the older age classes (medium, old, ancient). Fe-associated OC stocks are significantly different between age classes $(\mathrm{p}=0.0285)$ (Figure $4 \mathrm{~b}$, Table 1) and significantly increase from the young $(3.95 \pm 1.59 \mathrm{~kg} \mathrm{~m}-2)$ to the medium age class $(10.04 \pm 1.81 \mathrm{~kg}$ $\mathrm{m}-2)(\mathrm{p}=0.0346)$. Changes in Fe-associated OC are driven by an increased incorporation of OC in cryoturbated horizons as they increase in abundance along the soil chronosequence. 
Stocks of Fe-associated OC in cryoturbated horizons concurrently increase from around 8 $\%$ in the young age class to $42-75 \%$ Fe-associated OC of the total Fe-associated OC stock in the older age classes (medium, old, ancient) (Figure 4 b). This underlines the shift from mineral horizons contributing most to the Fe-associated OC and reactive Fe stock in young (0-50 years) permafrost soils of drained thaw lake basins to cryoturbated horizons storing most reactive Fe and associated OC with progressive soil development.

Table $1 \mid$ Overview of content, percentage and stock of reactive Fe and associated OC integrated over the whole soil profile and averaged over two replicate soil cores along the soil chronosequence. Reactive Fe is dithionitecitrate extractable Fe corrected by $\mathrm{NaCl}$ control extraction and Fe-associated OC is dithionite-citrate extractable OC corrected by $\mathrm{NaCl}$ control extraction and citrate background.

\begin{tabular}{|c|c|c|c|c|c|}
\hline \multirow[b]{2}{*}{ Content } & & Young & Medium & Old & Ancient \\
\hline & & & & & \\
\hline \multirow{2}{*}[\mathrm{mg}\mathrm{g}^{-1}\mathrm{DW}\text{-soil}{}^{-1}]{} & Reactive Fe & $71.11 \pm 13.07$ & $68.40 \pm 9.50$ & $67.18 \pm 4.60$ & $99.17 \pm 9.11$ \\
\hline & Fe-associated OC & $66.34 \pm 13.74$ & $128.12 \pm 44.79$ & $77.99 \pm 40.31$ & $139.25 \pm 48.04$ \\
\hline \multirow{2}{*}[\%]{} & Reactive Fe & $59.51 \pm 7.29$ & $56.55 \pm 5.09$ & $59.21 \pm 3.92$ & $73.66 \pm 7.02$ \\
\hline & Fe-associated OC & $10.96 \pm 0.21$ & $12.77 \pm 0.35$ & $8.03 \pm 0.52$ & $13.68 \pm 0.34$ \\
\hline \multirow{2}{*}[\mathrm{kg}\mathrm{m}^{-2}]{} & Reactive Fe & $6.22 \pm 0.50$ & $6.44 \pm 0.68$ & $6.18 \pm 0.31$ & $6.40 \pm 0.63$ \\
\hline & Fe-associated OC & $3.95 \pm 1.96$ & $10.04 \pm 5.44$ & $5.38 \pm 3.35$ & $8.92 \pm 4.84$ \\
\hline
\end{tabular}



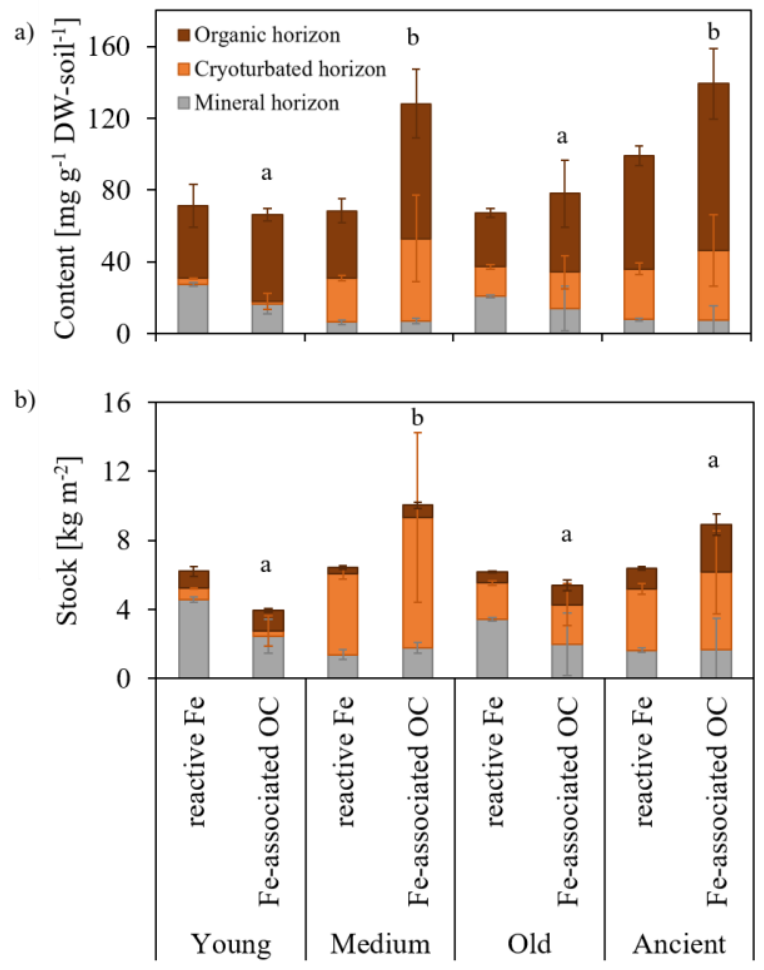

Figure 4 | Reactive Fe and associated OC a) content in $\mathrm{mg} \mathrm{g}^{-1} \mathrm{DW}$-soil $\mathrm{l}^{-1}$ and b) stock in $\mathrm{kg} \mathrm{m}^{-2}$ of in distinct soil horizons (organic: brown, cryoturbated/buried: orange, grey: mineral) along the soil chronosequence. Distribution of reactive Fe and associated OC contents highlight the role of organic horizons, whereas cryoturbated horizons are more important regarding stocks along the soil chronosequence. Reactive Fe is dithionite-citrate extractable Fe corrected by $\mathrm{NaCl}$ control extraction and Fe-associated $\mathrm{OC}$ is dithionite-citrate extractable OC corrected by $\mathrm{NaCl}$ control extraction and citrate background. Error bars represent a combined range of duplicate extractions per horizon of replicate soil cores. Significant differences between age classes are highlighted with letters $a$ and $b$.

\subsection{The nature of Fe-OC associations}

\subsubsection{Differences in Fe mineral crystallinity between soil horizons}

The crystallinity of Fe minerals can highly impact their capacity to interact with OC (Herndon et al., 2017). We therefore performed ${ }^{57} \mathrm{Fe}$-specific Mössbauer spectroscopy analysis at $77 \mathrm{~K}$ and $5 \mathrm{~K}$ to identify and quantify the relative abundances of Fe minerals. Mössbauer transmission spectra of organic horizons of the young and ancient age class showed similar properties for spectra collected at $77 \mathrm{~K}$ (Figure SI $5 \mathrm{a}, \mathrm{b}$, Table SI 4). The absence of a magneticordering phase at $77 \mathrm{~K}$ and the presence of a sextet in the Mössbauer spectra collected at $5 \mathrm{~K}$ suggests the presence of a poorly crystalline Fe(III) mineral phase with hyperfine field parameters 
similar to ferrihydrite (Figure SI 5 a, b, Figure SI 6 a, b, Table SI 4). This supports findings from selective extractions in organic horizons where reactive Fe minerals (which would include ferrihydrite) account for almost all of the total extractable Fe pool (Table SI 3). In cryoturbated and mineral horizons, $77 \mathrm{~K}$ Mössbauer spectra indicated the presence of an additional ferrous Fe mineral phase in both the young and ancient age class (Figure $5 \mathrm{c}, \mathrm{d}, \mathrm{e}, \mathrm{f}$ ) which undergoes magnetic ordering only at $5 \mathrm{~K}$ (Figure SI $6 \mathrm{c}$, d, e, f, Table SI 4). This can be typical for a poorly crystalline $\mathrm{Fe}(\mathrm{II})$ mineral phase such as vivianite, siderite or $\mathrm{Fe}(\mathrm{II})$-rich phyllosilicates although a clear identification could not be achieved by Mössbauer spectroscopy only. Phyllosilicates are not targeted by the dithionite-citrate extraction but will dissolve to a small extent in the $6 \mathrm{M} \mathrm{HCl}$ extraction. A poorly crystalline Fe(II) mineral such as vivianite would likely dissolve in the dithionite-citrate extraction (Williams et al., 1980). Moreover, the preparation of the sample material under oxic conditions might lead to the abiotic oxidation of such oxygen sensitive ferrous Fe minerals. Taken this into consideration, and the lower abundance of reactive Fe minerals in the total extractable Fe pool compared to organic horizons (Table SI 3), suggests that the observed phase is probably an Fe(II)-bearing phyllosilicate (Poulton \& Canfield, 2005; Raiswell et al., 1994). Overall, Mössbauer spectroscopy enabled the identification of ferrihydrite as the poorly crystalline mineral phase most abundant in organic horizons with lower abundance due to a more pronounced $\mathrm{Fe}(\mathrm{II})$ phase in cryoturbated and mineral horizons. Fe minerals of higher crystallinity such as magnetite are typically generated by dissimilatory Fe(III) reduction (Lovley et al., 1987) and present in permafrost soils from northern Alaska (Lipson et al., 2010), but are not involved in Fe-OC associations found in our study. Unlike Sowers et al. (2020) which investigated a Yedoma chronosequence over 36000 years, we did not observe a change in Fe mineral crystallinity with soil development, but rather a change in Fe mineral crystallinity in soil horizons. Cryoturbated and mineral horizons contain similar Fe mineral phases in our study, but differ greatly in their amount of Fe-associated OC. Thus, we conclude that Fe mineral crystallinity does not solely affect the association of OC in permafrost soils of drained thaw lake basins, but is potentially influenced by the type of interaction between $\mathrm{OC}$ and reactive Fe minerals. 
3.2.2 Co-precipitation, chelation and aggregation primarily explain the nature of Fe-OC associations

$\mathrm{Fe}$-associated $\mathrm{OC}$ to reactive Fe ratios (OC:Fe) obtained by the dithionite-citrate extraction can indicate the mechanism of Fe-OC interactions. A mass ratio over 0.22 is indicative for Fe-OC associations predominantly formed by co-precipitation or chelation (Wagai \& Mayer, 2007). Below an OC:Fe mass ratio of 0.22 , OC is mainly assumed to be sorbed onto Fe minerals. In the present study, $86 \%$ of the permafrost samples exceed an OC:Fe mass ratios of 0.22 with significant differences between soil horizons ( $\mathrm{p}=0.01$, Kruskall Wallis test) (Figure 6). Organic horizons consistently exceed a OC:Fe mass ratio of 0.22 with ratios between 0.57 and 5.05. They are significantly different from mineral horizons $(\mathrm{p}=0.01)$ that show lower OC:Fe mass ratios $(0$ to 2.02). OC:Fe mass ratios in cryoturbated horizons range between 0 and 4.72 . Given the release of OC bound in soil microaggregate structures during dithionite-citrate extraction (Wagai \& Mayer, 2007), high OC:Fe mass ratios indicate the contribution of aggregation.

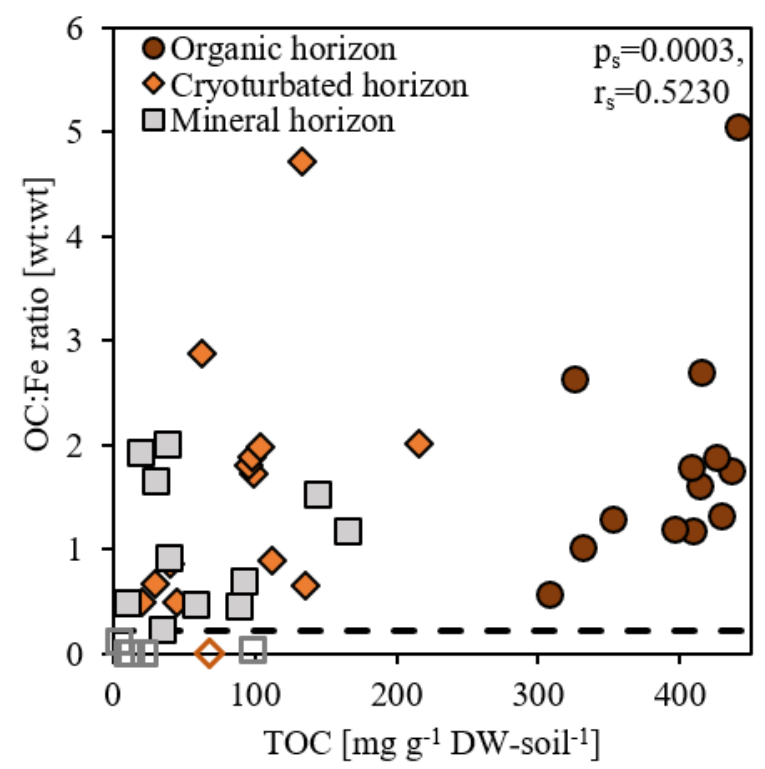

Figure 5 | OC:Fe mass ratios in relation to the TOC content in $\mathrm{mg}^{-1} \mathrm{DW}$-soil ${ }^{-1}$ separated into organic horizons (brown circle), cryoturbated/buried horizons (orange diamond) and mineral horizons (grey square) of replicate cores $(1,2)$ from four age classes (young, medium, old, ancient) of drained thaw lake basins from Alaska. $O C$ :Fe mass ratios were calculated using reactive Fe and Fe-associated OC contents. Reactive Fe is dithionite-citrate extractable $\mathrm{Fe}$ corrected by $\mathrm{NaCl}$ control extraction and $\mathrm{Fe}$-associated $\mathrm{OC}$ is dithionite-citrate extractable OC corrected by $\mathrm{NaCl}$ control extraction and citrate background. The dashed line represents the presumed threshold for sorption of reactive Fe minerals on natural organic matter (Wagai and Mayer, 2007). OC:Fe mass ratios largely 
exceeding 0.22, indicate co-precipitation or chelation of organic compounds. Samples exceeding this threshold are illustrated as filled symbols, whereas framed symbols are below a ratio of 0.22 .

Cryoturbated horizons show a high proportion of particulate organic matter where plant residues can for example promote soil aggregate formation by providing a priming structure for aggregating mineral particles (Mueller et al., 2017; Prater et al., 2020). The intricate connection of reactive Fe minerals, organic matter and the soil matrix in a cryoturbated horizon (medium 2) is illustrated by using combined SEM and NanoSIMS analysis (Figure 5). The backscattered SEM image showed particulate organic matter (POM) and clay minerals (mi) enclosed by Fe minerals $(\mathrm{FeO})$ in the soil cross section and delimited quartz grains (q) (Figure $5 \mathrm{a}$ ). Microscale distributions showed a close spatial association of Fe minerals visualized as ${ }^{56} \mathrm{Fe}^{16} \mathrm{O}$ - intertwined with POM as ${ }^{12} \mathrm{C}^{14} \mathrm{~N}$ - and clay and silt minerals shown as ${ }^{27} \mathrm{Al}^{16} \mathrm{O}$ - as detected by NanoSIMS (Figure $5 \mathrm{~b}, \mathrm{c}$ ).

This highlights the role of reactive Fe minerals in retaining OC in soil horizons with emphasis on cryoturbated horizons. Thus, we propose that OC is primarily co-precipitated, chelated or aggregated with reactive Fe minerals.
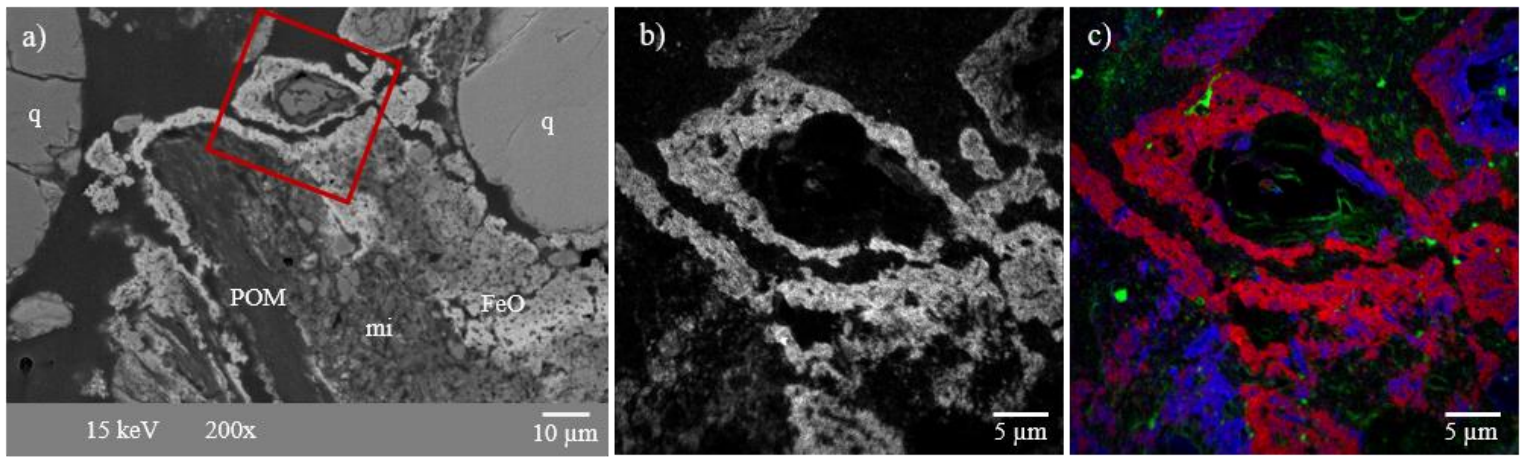

Figure 6 | Cross section of an embedded intact soil core derived from the permafrost layer to illustrate the intricate connection of $\mathrm{Fe}$ oxides $(\mathrm{FeO})$ with soil organic matter (i.e. particulate organic matter, POM) and the soil matrix (quartz grains, q; clay minerals, mi). a) Backscattered SEM image showing the incrustation of particulate organic matter and silt and clay minerals (mi) by FeO (brighter zones in backscattered SEM image). The red square indicates the NanoSIMS measurement spot $(b, c)$. b) Microscale distribution of Fe measured as ${ }^{56} \mathrm{Fe}^{16} \mathrm{O}^{-}$by $\mathrm{NanoSIMS}$ c) Composite image of $\mathrm{Fe}\left(\mathrm{red},{ }^{56} \mathrm{Fe}{ }^{16} \mathrm{O}^{-}\right)$, organic matter (green, $\left.{ }^{12} \mathrm{C}^{14} \mathrm{~N}^{-}\right)$and aluminium $\left(\right.$blue, $\left.{ }^{27} \mathrm{Al}{ }^{16} \mathrm{O}^{-}\right)($detailed description of sample in Mueller et al. (2017)).

The type of Fe-OC interactions seems to be governed to a certain extent by the amount of TOC present in soil horizons, as supported by significant correlation between OC:Fe mass ratios 
and TOC content $\left(\mathrm{p}_{\mathrm{s}}=0.0003, \mathrm{r}_{\mathrm{s}}=0.5230\right)$. Furthermore, the association of OC seems not to be limited by the amount of reactive Fe in our permafrost soil cores, in contrast to Fe-OC associations in forest soils (Zhao et al., 2016). The Fe-associated OC in our study largely exceeds the theoretical maximum of sorbed OC onto Fe (oxyhydr)oxides, calculated as 0.22 times the reactive Fe content (Herndon et al., 2017) (Figure SI 4). High OC:Fe mass ratios in distinct soil horizons can possibly be explained by changes in solubility of redox active metals (Eusterhues et al., 2005), as it can also be observed at the redox interface in permafrost affected soils.

Besides the amount of $\mathrm{OC}, \mathrm{pH}$ also influences the nature of the Fe-OC association (Wagai \& Mayer, 2007). On average, higher OC:Fe mass ratios can be found in older age classes where $\mathrm{pH}$ is generally lower and TOC is higher compared to the young age class (young $=0.55 \pm 0.54$, medium $=1.85 \pm 0.76$, old $=1.03 \pm 0.59$, ancient $=1.68 \pm 1.65)($ Kao-Kniffin et al., 2015). In summary, our results show that Fe-OC associations are primarily formed by co-precipitation, chelation and aggregation in drained thaw lake basins of northern Alaska which is in accordance with findings from other permafrost regions ( $\mathrm{Mu}$ et al., 2020; Patzner et al., 2020). Contrary findings in the same region, where Fe-OC associations are restricted to sorption (Herndon et al., 2017), highlights the heterogeneity of Fe-OC associations and the need for further investigations.

\subsection{Potential fate of Fe-OC associations under climate change}

The molecular diversity was long thought to be the main factor limiting the decomposition of organic matter. Lehmann et al. (2020) recently underlined that spatial and temporal variations in the soil shape the functional complexity and collectively determine OC persistence. As permafrost soils are highly variable ecosystems with annual freeze-thaw cycles, Fe-OC associations are considered to play an important role in retaining OC under a changing climate. Increasing permafrost thaw can result in waterlogged and anoxic conditions under which $\mathrm{Fe}$ minerals are dissolved by dissimilatory $\mathrm{Fe}(\mathrm{III})$ reducing microorganisms that releases the Feassociated OC (Patzner et al., 2020). By this, greenhouse gas emissions could be exaggerated by microbial $\mathrm{Fe}(\mathrm{III})$ reduction which is directly coupled to $\mathrm{OC}$ mineralization leading to $\mathrm{CO}_{2}$ emissions (Lovley et al., 1987). As well as by the reductive dissolution of reactive Fe minerals mobilizing the previously bound OC which becomes available for microbial respiration. Additionally, $\mathrm{Fe}(\mathrm{III})$ reduction can also be coupled to other microbial processes such as anaerobic 
oxidation of methane which influences greenhouse gas emissions (van Huissteden et al., 2011) and thus the response of permafrost soils to climate change.

At the Arctic Coastal Plain of northern Alaska, microbial Fe(III) reduction contributes up to $63 \%$ to the total respiration (Lipson et al., 2013) which emphasizes the important role of Fe minerals in the association with OC. Thermokarst regions of the Arctic Coastal Plain in Alaska are assumed to shift from a stable (Hinkel et al., 2007) to a susceptible environment under future climate (Nitze et al., 2020). Due to the lack of ground ice-wedge build-up under future climate scenarios, it is expected that thermokarst lakes will no longer follow the long postulated thermokarst lake cycle where reformation of thermokarst lakes was expected after around 5500 years of drainage (Bouchard et al., 2017; Fuchs et al., 2019; Jorgenson \& Shur, 2007). Consequently, $\mathrm{OC}$ introduced by cryoturbation can be associated and stabilized by reactive $\mathrm{Fe}$ minerals under increasing soil drainage which promotes oxic conditions (Herndon et al., 2020). This association potentially preserves OC over thousands of years mitigating the rapid loss of respired $\mathrm{C}$ as greenhouse gases to the atmosphere.

\section{Conclusions}

We found that high amounts of OC are associated with reactive Fe minerals, identified as ferrihydrite, in soils forming on drained thaw lake basins in northern Alaska. These associations form predominantly by co-precipitation or chelation in addition to aggregation mechanisms. Even though organic horizons account for the highest content of reactive Fe and associated OC, the importance of cryoturbated horizons becomes apparent when stocks of reactive $\mathrm{Fe}$ and $\mathrm{Fe}$ associated OC are considered. We thus postulate that the increase of cryoturbation with progressive soil development controls the increase of Fe-associated OC already within the first 50 years after thaw lake drainage. These observations have important implications under climate change for other thermokarst landscapes as found in northern Siberia and Canada (Grosse et al., 2006; van Huissteden et al., 2011) and for OC rich permafrost soils in general (Sowers et al., 2020). 


\section{Acknowledgments}

We thank Jenny Kao-Kniffin, James Bockheim and Kenneth Hinkel for the invitation to join the 2010 expedition, the joint work in the field and all logistic assistance. We are grateful for assistance in field work and sampling by Christine Mlot and the Barrow Arctic Science Consortium (BASC). The funding for the sampling campaign was provided by the NSF Postdoctoral Fellowship in Polar Regions Research (\#0852036). We thank Marie Greiner and Miroslava Malusova for assistance in the lab, Ellen Röhm for OC measurements and Johannes Lugmeier for NanoSIMS measurements. We are grateful for the financial support from the German Science Foundation (DFG) in the frame of the "Initiation of International Collaboration" program (MU 3021/2-1), for support from the German Academic Scholar Foundation (scholarship to MSP) and for support through the "Programme for the Promotion of Junior Researchers" award to CB from the University of Tübingen. The authors further acknowledge infrastructural support by the Deutsche Forschungsgemeinschaft (DFG, German Research Foundation) under Germany's Excellence Strategy, cluster of Excellence EXC2124, project ID 390838134.

\section{Data availability statement}

The dataset supporting the findings of this study is available at Zenodo and can be accessed via https://doi.org/10.5281/zenodo.5171830 (Joss et al., 2021).

\section{Conflicts of Interest}

The authors declare no conflict of interest.

\section{Authors contribution}

C.B, M.P and A.K formulated the original hypothesis. H.J, M.P, C.B and A.K designed the project. C.M collected and provided the permafrost soil samples and conducted the nanoSIMS analysis. M.M performed the Mössbauer analysis. H.J conducted analyses in the laboratory and wrote the original draft of the manuscript. All authors were responsible for data evaluation and interpretation. All authors discussed the data, reviewed and edited the manuscript and have read and agreed to the published version of the manuscript. 


\section{References}

Amstaetter, K., Borch, T., \& Kappler, A. (2012). Influence of humic acid imposed changes of ferrihydrite aggregation on microbial Fe(III) reduction. Geochimica Et Cosmochimica Acta, 85, 326-341. https://doi.org/10.1016/j.gca.2012.02.003

Bockheim, J. G. (2007). Importance of Cryoturbation in Redistributing Organic Carbon in Permafrost-Affected Soils. Soil Science Society of America Journal, 71(4), 1335. https://doi.org/10.2136/sssaj2006.0414N

Bouchard, F., MacDonald, L. A., Turner, K. W., Thienpont, J. R., Medeiros, A. S., Biskaborn, B. K. et al. (2017). Paleolimnology of thermokarst lakes: a window into permafrost landscape evolution. Arctic Science, 3(2), 91-117. https://doi.org/10.1139/as-2016-0022

Chen, C., Hall, S. J., Coward, E., \& Thompson, A. (2020). Iron-mediated organic matter decomposition in humid soils can counteract protection. Nature Communications, 11(1), 2255. https://doi.org/10.1038/s41467-020-16071-5

Cornell, R. M., \& Giovanoli, R. (1988). Acid dissolution of akaganeite and lepidocrocite: The effect of crystal morphology. Clays and Clay Minerals, 36(5), 385-390. Retrieved from http://www.clays.org/journal/archive/volume\%2036/36-5-385.pdf

Cornell, R. M., \& Schwertmann, U. (2003). The Iron Oxides: Structure, Properties, Reactions, Occurences and Uses.

Coward, E. K., Thompson, A. T., \& Plante, A. F. (2017). Iron-mediated mineralogical control of organic matter accumulation in tropical soils. Geoderma, 306, 206-216. https://doi.org/10.1016/j.geoderma.2017.07.026

Estop - Aragones, C., Olefeldt, D., Abbott, B. W., Chanton, J. P., Czimczik, C. I., Dean, J. F. et al. (2020). Assessing the Potential for Mobilization of Old Soil Carbon After Permafrost Thaw: A Synthesis of 14 C Measurements From the Northern Permafrost Region. Global Biogeochemical Cycles, 34(9). https://doi.org/10.1029/2020GB006672

Eusterhues, K., Rumpel, C., \& Kögel-Knabner, I. (2005). Organo-mineral associations in sandy acid forest soils: importance of specific surface area, iron oxides and micropores. European Journal of Soil Science, 56, 753-763. https://doi.org/10.1111/j.1365-2389.2005.00710.x 
Fisher, B. J., Moore, O. W., Faust, J. C., Peacock, C. L., \& März, C. (2020). Experimental evaluation of the extractability of iron bound organic carbon in sediments as a function of carboxyl content. Chemical Geology, 556, 119853. https://doi.org/10.1016/j.chemgeo.2020.119853

Foucher, D., Niessen, S., Fisher, J.-C., Kwokal, Ž., \& Mikac, N. (2000). The use of hydrochloric acid for determining solid-phase association of mercury in anoxic sediments. ESF Conference. Retrieved from https://www.bib.irb.hr/42381?rad=42381

Fuchs, M., Lenz, J., Jock, S., Nitze, I., Jones, B. M., Strauss, J. et al. (2019). Organic Carbon and Nitrogen Stocks Along a Thermokarst Lake Sequence in Arctic Alaska. Journal of Geophysical Research: Biogeosciences, 124(5), 1230-1247. https://doi.org/10.1029/2018JG004591

Grosse, G., Jones, B., \& Arp, C. (2013). Thermokarst Lakes, Drainage, and Drained Basins. https://doi.org/10.1016/B978-0-12-374739-6.00216-5

Grosse, G., Schirrmeister, L., \& Malthus, T. J. (2006). Application of Landsat-7 satellite data and a DEM for the quantification of thermokarst-affected terrain types in the periglacial Lena-Anabar coastal lowland. Polar Research, 25(1), 51-67. https://doi.org/10.1111/j.17518369.2006.tb00150.x

Hegler, F., Posth, N. R., Jiang, J., \& Kappler, A. (2008). Physiology of phototrophic iron(II)oxidizing bacteria: Implications for modern and ancient environments. FEMS Microbiology Ecology, 66(2), 250-260. https://doi.org/10.1111/j.1574-6941.2008.00592.x

Hemingway, J. D., Rothman, D. H., Grant, K. E., Rosengard, S. Z., Eglinton, T. I., Derry, L. A. et al. (2019). Mineral protection regulates long-term global preservation of natural organic carbon. Nature, 570(7760), 228-231. https://doi.org/10.1038/s41586-019-1280-6

Herndon, E. M., AlBashaireh, A., Singer, D., Roy Chowdhury, T., Gu, B., \& Graham, D. (2017). Influence of iron redox cycling on organo-mineral associations in Arctic tundra soil. Geochimica Et Cosmochimica Acta, 207, 210-231. https://doi.org/10.1016/j.gca.2017.02.034

Herndon, E. M., Kinsman - Costello, L., \& Godsey, S. (2020). Biogeochemical Cycling of Redox - Sensitive Elements in Permafrost - Affected Ecosystems. In K. Dontsova, Z. BaloghBrunstad, \& G. Le Roux (Eds.), Geophysical Monograph: v.248. Biogeochemical cycles: Ecological drivers and environmental impact (pp. 245-265). Washington, Hoboken: American Geophysical Union; Wiley. https://doi.org/10.1002/9781119413332.ch12 
Herndon, E. M., Yang, Z., Bargar, J., Janot, N., Regier, T. Z., Graham, D. E. et al. (2015). Geochemical drivers of organic matter decomposition in arctic tundra soils. Biogeochemistry, 126(3), 397-414. https://doi.org/10.1007/s10533-015-0165-5

Hinkel, K. M., Eisner, W. R., Bockheim, J. G., Nelson, F. E., Peterson, K. M., \& Dai, X. (2003). Spatial Extent, Age, and Carbon Stocks in Drained Thaw Lake Basins on the Barrow Peninsula, Alaska. Arctic, Antarctic, and Alpine Research, 35(3), 291-300. https://doi.org/10.1657/15230430(2003)035[0291:SEAACS]2.0.CO;2

Hinkel, K. M., Jones, B. M., Eisner, W. R., Cuomo, C. J., Beck, R. A., \& Frohn, R. (2007). Methods to assess natural and anthropogenic thaw lake drainage on the western Arctic coastal plain of northern Alaska. Journal of Geophysical Research, 112(F2). https://doi.org/10.1029/2006JF000584

Hopple, A. M., Wilson, R. M., Kolton, M., Zalman, C. A., Chanton, J. P., Kostka, J. et al. (2020). Massive peatland carbon banks vulnerable to rising temperatures. Nature Communications, 11(1), 2373. https://doi.org/10.1038/s41467-020-16311-8

Hugelius, G., Strauss, J., Zubrzycki, S., Harden, J. W., Schuur, E. A. G., Ping, C.-L. et al. (2014). Estimated stocks of circumpolar permafrost carbon with quantified uncertainty ranges and identified data gaps. Biogeosciences, 11(23), 6573-6593. https://doi.org/10.5194/bg-11-65732014

Jorgenson, M. T., \& Shur, Y. (2007). Evolution of lakes and basins in northern Alaska and discussion of the thaw lake cycle. Journal of Geophysical Research, 112(F2). https://doi.org/10.1029/2006JF000531

Joss, H., Patzner, M. S., Maisch, M., Mueller, C. W., Kappler, A., \& Bryce, C. (2021). Cryoturbation leads to iron-organic carbon associations along a permafrost soil chronosequence in northern Alaska. https://doi.org/10.5281/ZENODO.5171830

Kaiser, K., \& Guggenberger, G. (2000). The role of DOM sorption to mineral surfaces in the preservation of organic matter in soils. Organic Geochemistry. (31), 711-725.

Kao-Kniffin, J., Woodcroft, B. J., Carver, S. M., Bockheim, J. G., Handelsman, J., Tyson, G. W. et al. (2015). Archaeal and bacterial communities across a chronosequence of drained lake basins in Arctic Alaska. Scientific Reports, 5, 18165. https://doi.org/10.1038/srep18165 
Kögel-Knabner, I., Guggenberger, G., Kleber, M., Kandeler, E., Kalbitz, K., Scheu, S. et al. (2008). Organo-mineral associations in temperate soils: Integrating biology, mineralogy, and organic matter chemistry. Journal of Plant Nutrition and Soil Science, 171(1), 61-82. https://doi.org/10.1002/jpln.200700048

Lalonde, K., Ouellet, A., \& Gélinas, Y. (2012). The Rusty Sink: Iron and the preservation of organic matter in sediments, 483(7388), 198-200.

Lehmann, J., Hansel, C. M., Kaiser, C., Kleber, M., Maher, K., Manzoni, S. et al. (2020). Persistence of soil organic carbon caused by functional complexity. Nature Geoscience, 13(8), 529-534. https://doi.org/10.1038/S41561-020-0612-3

Liang, L., McCarthy, J. F., Jolley, L. W., McNabb, A., \& Mehlhorn, T. L. (1993). Iron dynamics: Transformation of $\mathrm{Fe}(\mathrm{II}) / \mathrm{Fe}(\mathrm{III})$ during injection of natural organic matter in a sandy aquifer. Geochimica Et Cosmochimica Acta. (57), 1987-1999.

Lipson, D. A., Jha, M., Raab, T. K., \& Oechel, W. C. (2010). Reduction of iron (III) and humic substances plays a major role in anaerobic respiration in an Arctic peat soil. Journal of Geophysical Research, 115. https://doi.org/10.1029/2009JG001147

Lipson, D. A., Raab, T. K., Goria, D., \& Zlamal, J. (2013). The contribution of Fe(III) and humic acid reduction to ecosystem respiration in drained thaw lake basins of the Arctic Coastal Plain. Global Biogeochemical Cycles, 27(2), 399-409. https://doi.org/10.1002/gbc.20038

Lovley, D. R., Stolz, J. F., Nord, G. L., \& Phillips, E. J. P. (1987). Anaerobic production of magnetite by a dissimilatory iron-reducing microorganism. Nature, 330(6145), 252-254. https://doi.org/10.1038/330252a0

Mehra, O. P., \& Jackson, M. L. (1960). Iron Oxide Removal from Soils and Clays by a DithioniteCitrate System Buffered with Sodium Bicarbonate. Clays and Clay Minerals, 7(1), 317-327. https://doi.org/10.1346/CCMN.1958.0070122

Moormann, F. R., \& van Breemen, N. (1978). Rice: soil, water, land: Int. Rice Res. Inst.

Mu, C. C., Zhang, T. J., Zhao, Q., Guo, H., Zhong, W., Su, H. et al. (2016). Soil organic carbon stabilization by iron in permafrost regions of the Qinghai-Tibet Plateau. Geophysical Research Letters, 43(19), 10,286-10,294. https://doi.org/10.1002/2016GL070071 
Mu, C., Zhang, F., Mu, M., Chen, X., Li, Z., \& Zhang, T. (2020). Organic carbon stabilized by iron during slump deformation on the Qinghai-Tibetan Plateau. CATENA, 187, 104282. https://doi.org/10.1016/j.catena.2019.104282

Mueller, C. W., Hoeschen, C., Steffens, M., Buddenbaum, H., Hinkel, K., Bockheim, J. G. et al. (2017). Microscale soil structures foster organic matter stabilization in permafrost soils. Geoderma, 293, 44-53. https://doi.org/10.1016/j.geoderma.2017.01.028

Mueller, C. W., Rethemeyer, J., Kao-Kniffin, J., Löppmann, S., Hinkel, K. M., \& Bockheim, J. G. (2015). Large amounts of labile organic carbon in permafrost soils of northern Alaska. Global Change Biology, 21(7), 2804-2817. https://doi.org/10.1111/gcb.12876

Mueller, C. W., Weber, P. K., Kilburn, M. R., Hoeschen, C., Kleber, M., \& Pett-Ridge, J. (2013). Advances in the Analysis of Biogeochemical Interfaces: NanoSIMS to investigate soil microenvironments. Advances in Agronomy, 121, 1-46. https://doi.org/10.1016/B978-0-12407685-3.00001-3

Nitze, I., Cooley, S. W., Duguay, C. R., Jones, B. M., \& Grosse, G. (2020). The catastrophic thermokarst lake drainage events of 2018 in northwestern Alaska: fast-forward into the future. The Cryosphere, 14(12), 4279-4297. https://doi.org/10.5194/tc-14-4279-2020

Olefeldt, D., Goswami, S., Grosse, G., Hayes, D., Hugelius, G., Kuhry, P. et al. (2016). Circumpolar distribution and carbon storage of thermokarst landscapes. Nature Communications, 7(1), 13043. https://doi.org/10.1038/ncomms13043

Osterkamp, T. E., \& Romanovsky, V. E. (1999). Evidence for warming and thawing of discontinuous permafrost in Alaska. Permafrost and Periglacial Processes, 10(1), 17-37. https://doi.org/10.1002/(SICI)1099-1530(199901/03)10:1<17::AID-PPP303>3.0.CO;2-4

Patzner, M. S., Mueller, C. W., Malusova, M., Baur, M., Nikeleit, V., Scholten, T. et al. (2020). Iron mineral dissolution releases iron and associated organic carbon during permafrost thaw. Nature Communications, 11(1), 6329. https://doi.org/10.1038/s41467-020-20102-6

Pehkonen, S. (1995). Determination of the oxidation states of iron in natural waters. A review. The Analyst, 120(11), 2655. https://doi.org/10.1039/an9952002655

Peltier, E., Dahl, A. L., \& Gaillard, J.-F. (2005). Metal speciation in anoxic sediments: When sulfides can be construed as oxides. Environmental Science \& Technology, 39(1), 311-316. https://doi.org/10.1021/es049212c 
Ping, C. L., Bockheim, J. G., Kimble, J. M., Michaelson, G. J., \& Walker, D. A. (1998). Characteristics of cryogenic soils along a latitudinal transect in arctic Alaska. Journal of Geophysical Research, 103(D22), 28917-28928. https://doi.org/10.1029/98JD02024

Polerecky, L., Adam, B., Milucka, J., Musat, N., Vagner, T., \& Kuypers, M. M. M. (2012). Look@nanosims--a tool for the analysis of nanoSIMS data in environmental microbiology. Environmental Microbiology, 14(4), 1009-1023. https://doi.org/10.1111/j.14622920.2011.02681.x

Porsch, K., \& Kappler, A. (2011). FeII oxidation by molecular O2 during HCl extraction. Environmental Chemistry, 8(2), 190. https://doi.org/10.1071/EN10125

Poulton, S. W., \& Canfield, D. E. (2005). Development of a sequential extraction procedure for iron: implications for iron partitioning in continentally derived particulates. Chemical Geology, 214(3-4), 209-221. https://doi.org/10.1016/j.chemgeo.2004.09.003

Prater, I., Zubrzycki, S., Buegger, F., Zoor-Füllgraff, L. C., Angst, G., Dannenmann, M. et al. (2020). From fibrous plant residues to mineral-associated organic carbon - the fate of organic matter in Arctic permafrost soils. https://doi.org/10.5194/bg-2020-52

Raiswell, R., Canfield, D. E., \& Berner, R. A. (1994). A comparison of iron extraction methods for the determination of degree of pyritisation and the recognition of iron-limited pyrite formation. Chemical Geology, 111(1-4), 101-110. https://doi.org/10.1016/0009-2541(94)90084-1

Rutledge, S., Campbell, D. I., Baldocchi, D., \& Schipper, L. A. (2010). Photodegradation leads to increased carbon dioxide losses from terrestrial organic matter. Global Change Biology, 16(11), 3065-3074. https://doi.org/10.1111/j.1365-2486.2009.02149.x

Schädel, C., Bader, M. K.-F., Schuur, E. A. G., Biasi, C., Bracho, R., Čapek, P. et al. (2016). Potential carbon emissions dominated by carbon dioxide from thawed permafrost soils. Nature Climate Change, 6(10), 950-953. https://doi.org/10.1038/nclimate3054

Schuur, E. A. G., McGuire, A. D., Schädel, C., Grosse, G., Harden, J. W., Hayes, D. J. et al. (2015). Climate change and the permafrost carbon feedback. Nature, 520(7546), 171-179. https://doi.org/10.1038/nature14338

Schwertmann, U. (1966). Inhibitory Effect of Soil Organic Matter on the Crystallization of Amorphous Ferric Hydroxide. Nature, 212(5062), 645-646. https://doi.org/10.1038/212645b0 
Schwertmann, U., \& Murad, E. (1988). The nature of an iron oxide - organic iron association in a peaty environment. Clay Minerals, 23, 291-299. Retrieved from http://citeseerx.ist.psu.edu/viewdoc/download? doi=10.1.1.607.6321\&rep=rep1\&type=pdf

Shields, M. R., Bianchi, T. S., Gélinas, Y., Allison, M. A., \& Twilley, R. R. (2016). Enhanced terrestrial carbon preservation promoted by reactive iron in deltaic sediments. Geophysical Research Letters, 43(3), 1149-1157. https://doi.org/10.1002/2015GL067388

Sowers, T. D., Wani, R. P., Coward, E. K., Fischel, M. H. H., Betts, A. R., Douglas, T. A. et al. (2020). Spatially Resolved Organomineral Interactions across a Permafrost Chronosequence. Environmental Science \& Technology, 54(5), 2951-2960. https://doi.org/10.1021/acs.est.9b06558 Stookey, L. L. (1970). Ferrozine---a new spectrophotometric reagent for iron. Analytical Chemistry, 42(7), 779-781. https://doi.org/10.1021/ac60289a016

Turetsky, M. R., Abbott, B. W., Jones, M. C., Anthony, K. W., Olefeldt, D., Schuur, E. A. G. et al. (2020). Carbon release through abrupt permafrost thaw. Nature Geoscience, 13(2), 138-143. https://doi.org/10.1038/s41561-019-0526-0

Van Huissteden, J., Berrittella, C., Parmentier, F. J. W., Mi, Y., Maximov, T. C., \& Dolman, A. J. (2011). Methane emissions from permafrost thaw lakes limited by lake drainage. Nature Climate Change, 1(2), 119-123. https://doi.org/10.1038/nclimate1101

Varadachari, C., Goswami, G., \& Ghosh, K. (2006). Dissolution of Iron Oxides. Clay Research. (25), 1-19. Retrieved from http://rcais.res.in/oxide_dissolution.pdf

Von Lützow, M., Kögel-Knabner, I., Ludwig, B., Matzner, E., Flessa, H., Ekschmitt, K. et al. (2008). Stabilization mechanisms of organic matter in four temperate soils: Development and application of a conceptual model. Journal of Plant Nutrition and Soil Science, 171(1), 111-124. https://doi.org/10.1002/jpln.200700047

Wagai, R., \& Mayer, L. M. (2007). Sorptive stabilization of organic matter in soils by hydrous iron oxides. Geochimica Et Cosmochimica Acta, 71(1), 25-35. https://doi.org/10.1016/j.gca.2006.08.047

Wagai, R., Mayer, L. M., Kitayama, K., \& Shirato, Y. (2013). Association of organic matter with iron and aluminum across a range of soils determined via selective dissolution techniques coupled 
with dissolved nitrogen analysis. Biogeochemistry, 112(1-3), 95-109. https://doi.org/10.1007/s10533-011-9652-5

Walter Anthony, K., Schneider von Deimling, T., Nitze, I., Frolking, S., Emond, A., Daanen, R. et al. (2018). 21st-century modeled permafrost carbon emissions accelerated by abrupt thaw beneath lakes. Nature Communications, 9(1), 3262. https://doi.org/10.1038/s41467-018-05738-9 Wang, Y., Xu, Y., Wei, D., Shi, L., Jia, Z., \& Yang, Y. (2020). Different chemical composition and storage mechanism of soil organic matter between active and permafrost layers on the Qinghai-Tibetan Plateau. Journal of Soils and Sediments, 20(2), 653-664. https://doi.org/10.1007/s11368-019-02462-9

Williams, J. D. H., Mayer, T., \& Nriagu, J. O. (1980). Extractability of Phosphorus from Phosphate Minerals Common in Soils and Sediments. Soil Science Society of America Journal, 44(3), 462465. https://doi.org/10.2136/sssaj1980.03615995004400030004x

Zhao, Q., Poulson, S. R., Obrist, D., Sumaila, S., Dynes, J. J., McBeth, J. M. et al. (2016). Ironbound organic carbon in forest soils: quantification and characterization. Biogeosciences, 13(16), 4777-4788. https://doi.org/10.5194/bg-13-4777-2016

\section{References from the Supporting Information}

Herndon E. M., AlBashaireh A., Singer D., Roy Chowdhury T., Gu B. and Graham D. (2017) Influence of iron redox cycling on organo-mineral associations in Arctic tundra soil. Geochimica et Cosmochimica Acta 207, 210-231.

Mueller C. W., Rethemeyer J., Kao-Kniffin J., Löppmann S., Hinkel K. M. and Bockheim J. G. (2015) Large amounts of labile organic carbon in permafrost soils of northern Alaska. Global change biology 21, 2804-2817.

Patzner M. S., Mueller C. W., Malusova M., Baur M., Nikeleit V., Scholten T., Hoeschen C., Byrne J. M., Borch T., Kappler A. and Bryce C. (2020) Iron mineral dissolution releases iron and associated organic carbon during permafrost thaw. Nat Commun 11, 6329.

Wagai R. and Mayer L. M. (2007) Sorptive stabilization of organic matter in soils by hydrous iron oxides. Geochimica et Cosmochimica Acta 71, 25-35. 
Supplementary information for

\title{
Cryoturbation leads to iron-organic carbon associations along a permafrost soil chronosequence in northern Alaska
}

\author{
Hanna Joss' ${ }^{1}$, Monique S. Patzner ${ }^{1}$, Markus Maisch ${ }^{1}$, Carsten W. Mueller ${ }^{2}$, Andreas \\ Kappler $^{1,3}$, Casey Bryce ${ }^{4 *}$ \\ ${ }^{1}$ Geomicrobiology, Center for Applied Geoscience, University of Tübingen, Germany \\ ${ }^{2}$ Department of Geosciences and Natural Resource Management, University of Copenhagen, \\ Denmark \\ ${ }^{3}$ Cluster of Excellence: EXC 2124: Controlling Microbes to Fight Infection, Tübingen, Germany \\ ${ }^{4}$ School of Earth Sciences, University of Bristol, UK
}

Corresponding author: Casey Bryce (casey.bryce@bristol.ac.uk)

*School of Earth Sciences, Wills Memorial Building, Queens Road, Bristol BS8 1RJ 
Supplementary figures

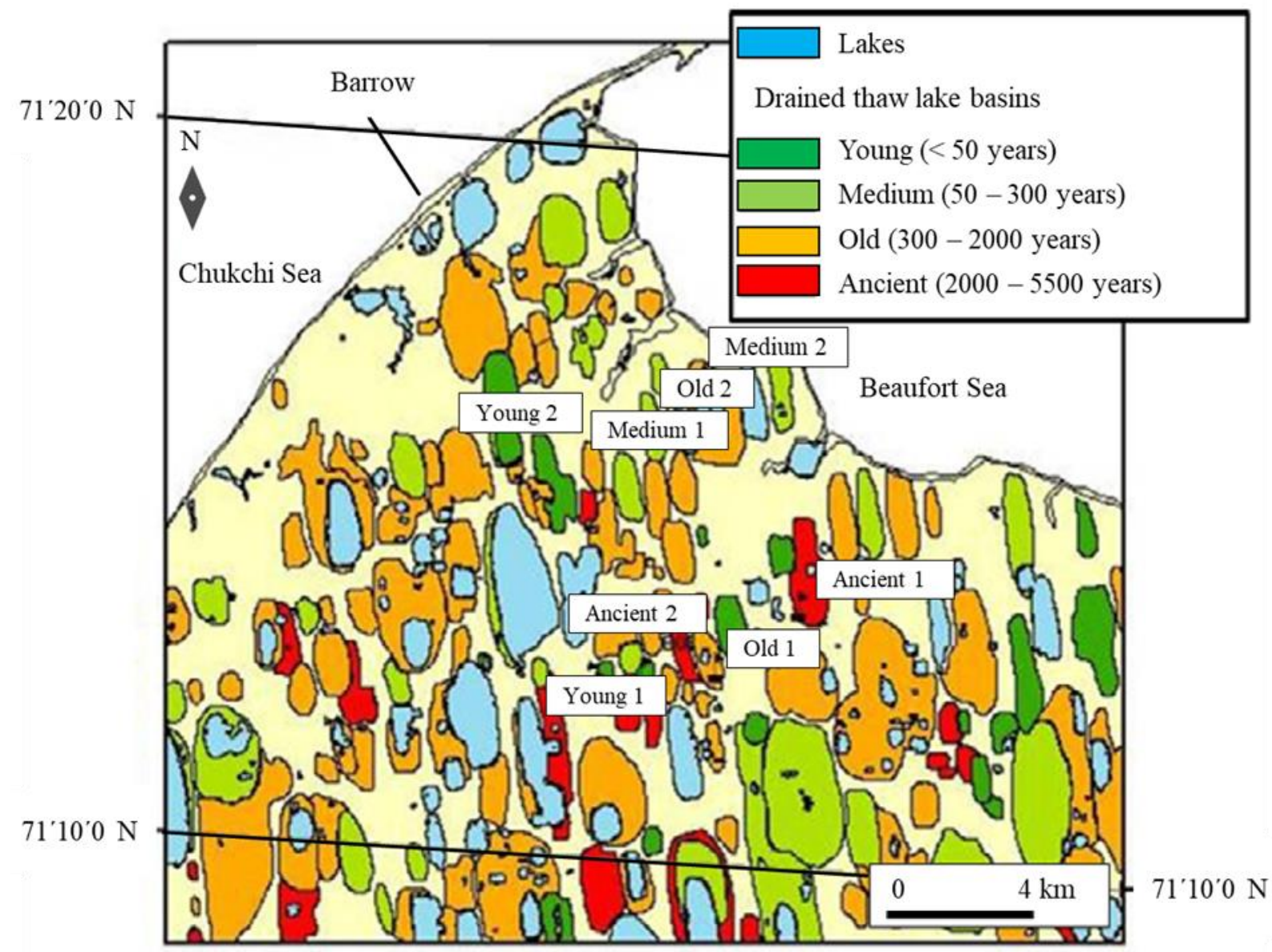

Figure SI 1 | Map of the area around Barrow, Alaska. Drained thaw lake basins are colored based on their age. Sampling sites are indicated within the map (modified from Mueller et al. (2015)). 


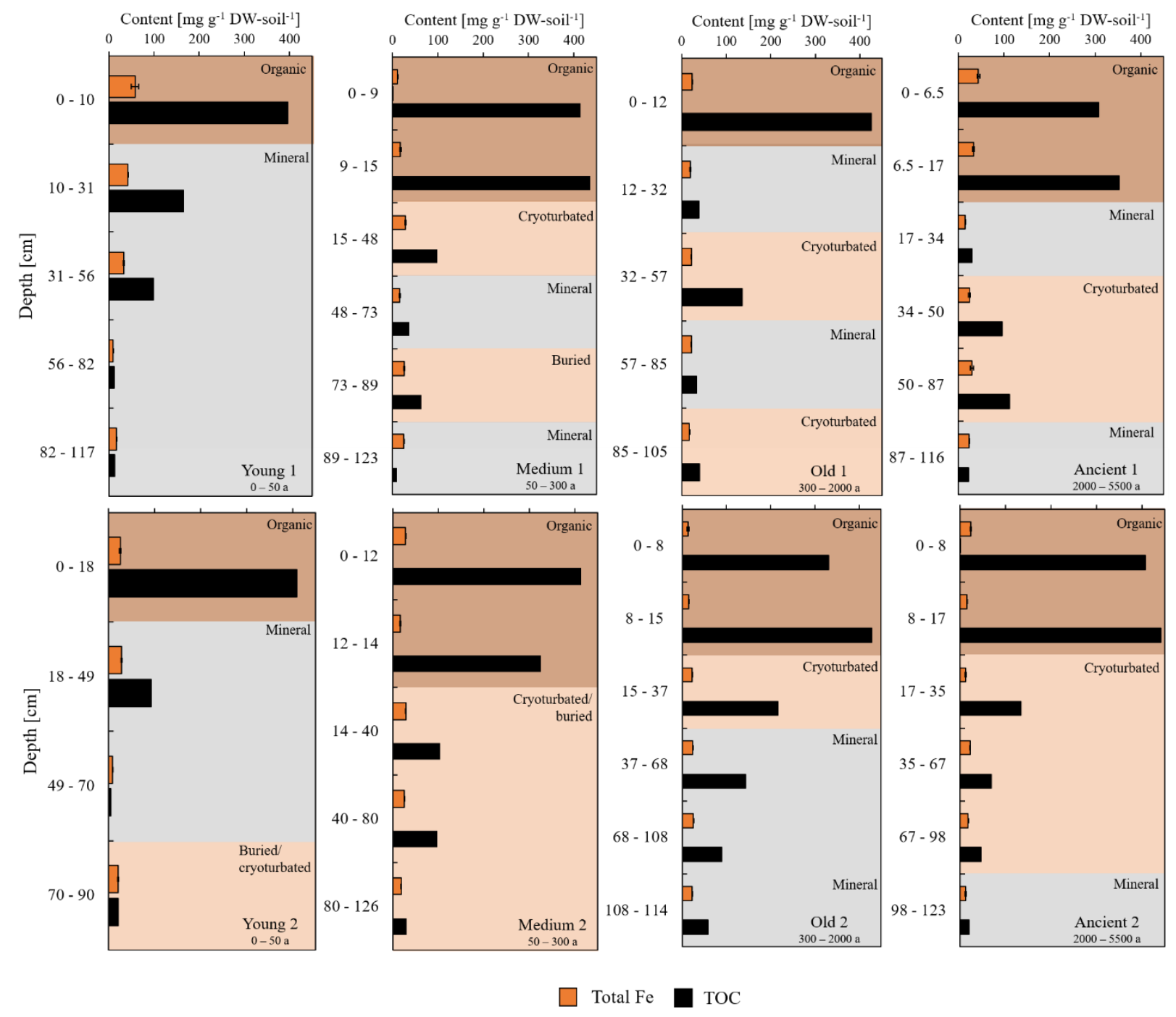

Figure SI 2 | Content of total Fe (orange, $6 \mathrm{M} \mathrm{HCl}$ extractable) and TOC (black) in $m g g^{-1} \mathrm{DW}$-soil ${ }^{-1}$ along the soil profile of replicate cores $(1,2)$ from four age classes (young, medium, old, ancient) of drained thaw lake basins from Alaska. Soil horizons are highlighted by color shading (brown: organic, beige: cryoturbated/buried, grey: mineral). Error bars of total Fe represent the range from duplicate extractions per each soil horizon. TOC data was obtained by Mueller et al. (2015). 

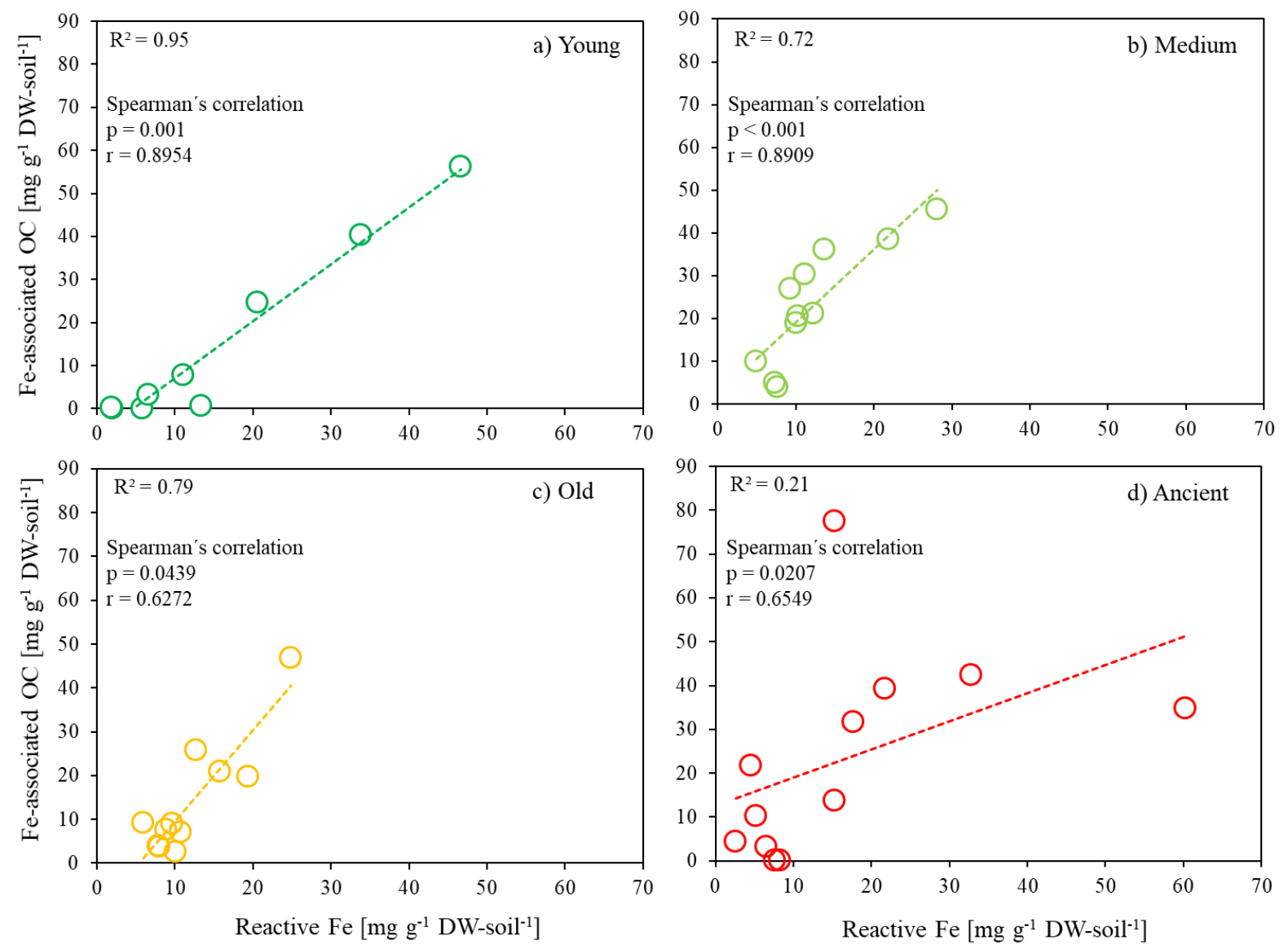

Figure SI 3 | Age dependent correlation of reactive Fe and Fe-associated OC of soil profiles of replicate cores $(1,2)$ from four age classes (young, medium, old, ancient) of drained thaw lake basins from Alaska. $(n=43)$. Divided into (a) young (dark green, $n=9)$, (b) medium (light green, $n=11)$, (c) old (yellow, $n=11)$ and (d) ancient (red, $n=12)$ illustrating increasing heterogeneity with age. Reactive Fe is dithionite-citrate extractable Fe corrected by $\mathrm{NaCl}$ control extraction and $\mathrm{Fe}$-associated $\mathrm{OC}$ is dithionite-citrate extractable $\mathrm{OC}$ corrected by $\mathrm{NaCl}$ control extraction and citrate background, presented as $\mathrm{mg}^{-1} \mathrm{DW}$-soil ${ }^{-1}$. Data points represent average from duplicate extraction with linear trendlines highlighted in respective colors. $R$ squared of linear regression and Spearman correlation coefficients are given within the figure. 


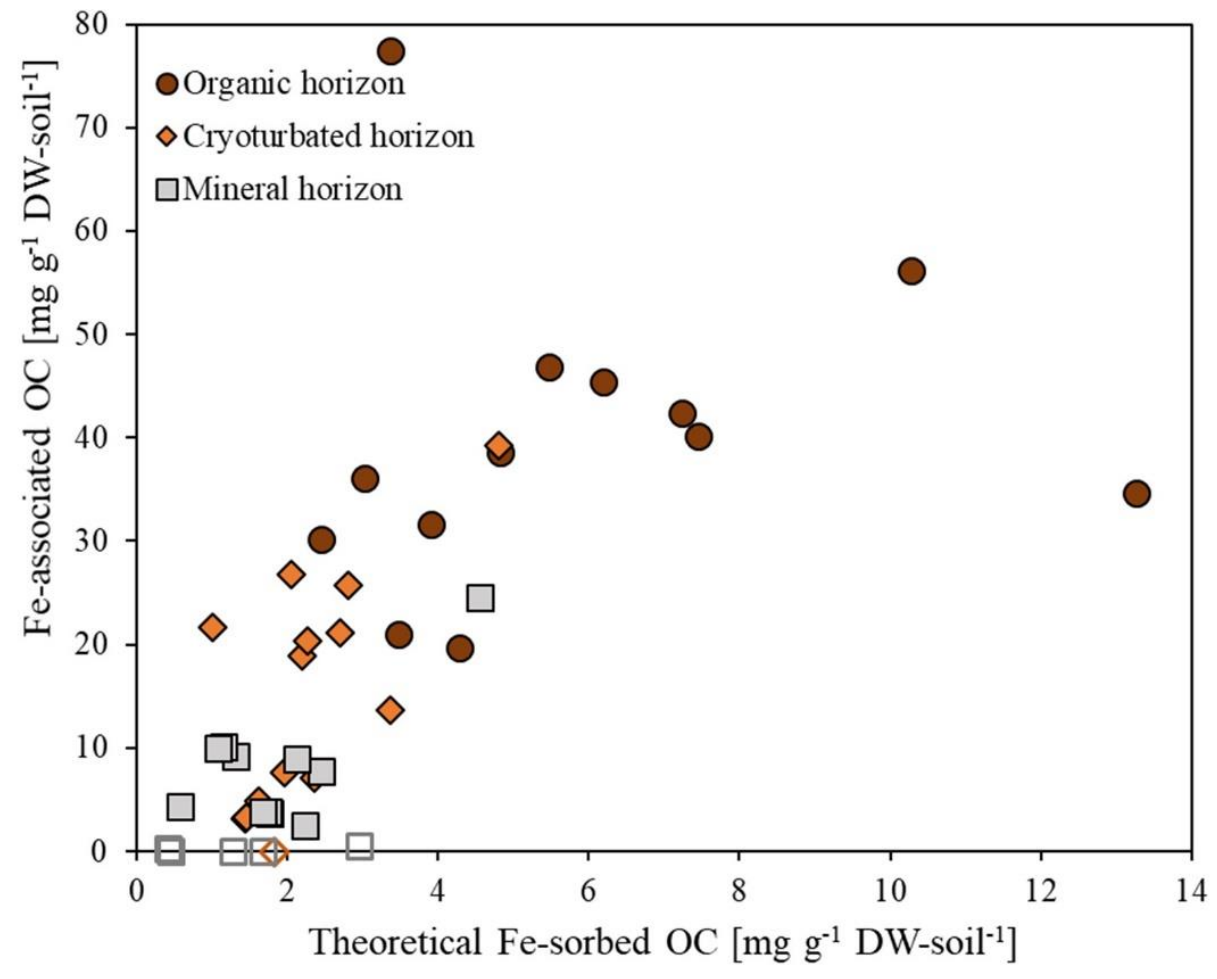

Figure SI 4 | Content of Fe-associated OC against theoretical maximum adsorption of OC to iron oxide surfaces, calculated as 0.22 times the reactive Fe content based on Wagai and Mayer (2007) following Herndon et al. (2017). Reactive Fe is dithionite-citrate extractable Fe corrected by $\mathrm{NaCl}$ control extraction and Fe-associated $\mathrm{OC}$ is dithionite-citrate extractable $\mathrm{OC}$ corrected by $\mathrm{NaCl}$ control extraction and citrate background, presented as $\mathrm{mg} \mathrm{g}^{-1} \mathrm{DW}$-soil ${ }^{-1}$. Filled symbols represent samples with OC:Fe mass ratios $>0.22$ and framed symbols are below a ratio of 0.22 . 
Supplementary tables

Table SI 1 | Pre-test for dithionite-citrate extraction to investigate the need of citrate as metal ion complexing agent. Without citrate, less reactive $F e$ and associated $O C$ were obtained, thus verifying the need of citrate despite the high OC background.

\begin{tabular}{lcc}
\hline Treatment & $\begin{array}{c}\text { Reactive Fe } \\
{\left[\mathrm{mg} \mathrm{g}^{-1}\right.}\end{array}$ & $\left.\begin{array}{c}\text { Fe-associated OC } \\
\text { DW-soil }\end{array}{ }^{-1}\right]$ \\
\hline $\begin{array}{l}\text { Sodium dithionite }+ \\
\text { NaCl/bicarbonate solution }\end{array}$ & $6.66 \pm 1.68$ & $1045.48 \pm 85.77$ \\
$\begin{array}{l}\text { Sodium dithionite }+ \\
\text { citrate/bicarbonate solution }\end{array}$ & $15.29 \pm 4.85$ & $2638.76 \pm 243.05$ \\
\hline
\end{tabular}

Table SI 2 | Effect of sample drying on reactive Fe and Fe-associated OC content in permafrost soil samples from a palsa transition zone collected in Abisko, Sweden (data comparable to Patzner et al. (2020)). Reactive Fe is dithionite-citrate extractable Fe corrected by $\mathrm{NaCl}$ control extraction and $\mathrm{Fe}$-associated $\mathrm{OC}$ is dithionite-citrate extractable $\mathrm{OC}$ corrected by $\mathrm{NaCl}$ control extraction and citrate background, presented as $m g g^{-1} \mathrm{DW}$-soil ${ }^{-1}$.

\begin{tabular}{|c|c|c|}
\hline \multirow[t]{2}{*}{ Treatment } & Reactive Fe & Fe-associated OC \\
\hline & \multicolumn{2}{|c|}{$\left[\mathrm{mg} \mathrm{g}^{-1} \text { DW-soil }{ }^{-1}\right]^{*}$} \\
\hline anoxic & & \\
\hline $60^{\circ} \mathrm{C}$ dried & $7.38 \pm 0.25$ & $86.64 \pm 15.03$ \\
\hline $\begin{array}{l}\text { air dried } \\
\text { oxic }\end{array}$ & $7.13 \pm 0.09$ & $94.75 \pm 29.46$ \\
\hline $60^{\circ} \mathrm{C}$ dried & $6.84 \pm 0.12$ & $82.81 \pm 7.31$ \\
\hline air dried & $6.41 \pm 0.19$ & $87.58 \pm 5.33$ \\
\hline
\end{tabular}

*not $\mathrm{NaCl}$ control corrected 
1 Table SI 3 | Summary table of bulk density, content, stock and relative amount of reactive Fe and Fe-associated OC, OC:Fe mass ratio,

2 total Fe, control Fe and OC and TOC of all soil horizons from replicate soil cores $(1,2)$ along a soil chronosequence of drained thaw

3 lake basins from Alaska. Reactive Fe is dithionite-citrate extractable Fe corrected by NaCl control extraction and Fe-associated OC is

4 dithionite-citrate extractable $\mathrm{OC}$ corrected by $\mathrm{NaCl}$ control extraction and citrate background. Colors indicate organic horizons

5 (brown), cryoturbated/buried horizons (light orange) and mineral horizons (grey). Values represent the average and range of duplicate

6 extractions.

\begin{tabular}{|c|c|c|c|c|c|c|c|c|c|c|c|c|}
\hline & $\begin{array}{c}\text { Bulk } \\
\text { density }\end{array}$ & $\begin{array}{c}\text { Reactive Fe } \\
\text { (control corrected) }\end{array}$ & $\begin{array}{l}\text { Reactive Fe stock } \\
\text { (control corrected) }\end{array}$ & $\begin{array}{l}\text { Relative amount } \\
\text { reactive } \mathrm{Fe}\end{array}$ & $\begin{array}{l}\text { Fe-associated OC } \\
\text { (control corrected) }\end{array}$ & $\begin{array}{l}\text { Fe-associated OC stock } \\
\text { (control corrected) }\end{array}$ & $\begin{array}{c}\text { Relative amount } \\
\text { Fe-associated OC }\end{array}$ & $\begin{array}{c}\mathrm{OC}: \mathrm{Fe} \\
\text { ratio }\end{array}$ & Total Fe & Control Fe & "TOC & Control OC \\
\hline & $\mathrm{g} \mathrm{cm}^{-3}$ & $\mathrm{mg} \mathrm{g}^{-1}$ & $\mathrm{~kg} \mathrm{~m}^{-2}$ & $\%$ of tot. $\mathrm{Fe}$ & $\mathrm{mg} \mathrm{g}^{-1}$ & $\mathrm{~kg} \mathrm{~m}^{-2}$ & $\%$ of TOC & & $\mathrm{mg} \mathrm{g}^{-1}$ & $\mathrm{mg} \mathrm{g}^{-1}$ & $\mathrm{mg} \mathrm{g}^{-1}$ & $\mathrm{mg} \mathrm{g}^{-1}$ \\
\hline \multicolumn{13}{|c|}{ Young $1(0-50$ a) } \\
\hline $0-10 \mathrm{~cm}$ & 0.29 & $46.68 \pm 5.96$ & $1.34 \pm 0.17$ & $80.60 \pm 21.69$ & $56.19 \pm 2.86$ & $1.62 \pm 0.08$ & $14.19 \pm 0.72$ & 1.20 & $57.91 \pm 8.19$ & $0.10 \pm 0.02$ & 395.98 & $22.45 \pm 1.95$ \\
\hline $10-31 \mathrm{~cm}$ & 0.57 & $20.66 \pm 0.21$ & $2.48 \pm 0.03$ & $49.60 \pm 0.91$ & $24.54 \pm 0.32$ & $2.94 \pm 0.04$ & $14.80 \pm 0.19$ & 1.19 & $41.66 \pm 0.34$ & $0.09 \pm 0.00$ & 165.85 & $6.47 \pm 0.17$ \\
\hline $31-56 \mathrm{~cm}$ & 0.39 & $13.43 \pm 0.29$ & $1.30 \pm 0.03$ & $41.18 \pm 2.39$ & $0.50 \pm 2.12$ & $0.05 \pm 0.21$ & $0.50 \pm 2.14$ & 0.04 & $32.61 \pm 1.18$ & $0.02 \pm 0.00$ & 99.05 & $2.21 \pm 0.00$ \\
\hline $56-82 \mathrm{~cm}$ & 1.26 & $2.05 \pm 0.16$ & $0.67 \pm 0.05$ & $22.77 \pm 2.17$ & bdl \pm bdl & bdl \pm bdl & $\mathrm{bdl} \pm \mathrm{bdl}$ & bdl & $9.02 \pm 0.16$ & $\mathrm{bdl} \pm \mathrm{bdl}$ & 11.06 & $0.78 \pm 0.08$ \\
\hline $82-117 \mathrm{~cm}$ & 0.79 & $5.84 \pm 0.03$ & $1.62 \pm 0.01$ & $35.70 \pm 0.24$ & bdl \pm bdl & bdl \pm bdl & bdl \pm bdl & bdl & $16.37 \pm 0.04$ & bdl \pm bdl & 13.07 & $0.61 \pm 0.01$ \\
\hline Total & & $88.67 \pm 6.65$ & $7.42 \pm 0.29$ & $56.27 \pm 3.61$ & $81.23 \pm 5.31$ & $4.61 \pm 0.33$ & $11.86 \pm 0.77$ & & $157.56 \pm 9.90$ & $0.21 \pm 0.02$ & 685.01 & $32.53 \pm 2.20$ \\
\hline \multicolumn{13}{|c|}{ Young 2 (0-50 a) } \\
\hline $0-18 \mathrm{~cm}$ & 0.11 & $33.90 \pm 5.97$ & $0.64 \pm 0.11$ & $134.64 \pm 9.26$ & $40.21 \pm 0.63$ & $0.77 \pm 0.01$ & $9.84 \pm 0.15$ & 1.19 & $25.18 \pm 1.70$ & $0.07 \pm 0.01$ & 408.71 & $14.67 \pm 0.20$ \\
\hline $18-49 \mathrm{~cm}$ & 0.77 & $11.15 \pm 0.35$ & $2.65 \pm 0.08$ & $39.63 \pm 2.17$ & $7.76 \pm 0.26$ & $1.85 \pm 0.06$ & $8.45 \pm 0.28$ & 0.70 & $28.13 \pm 1.52$ & $0.05 \pm 0.00$ & 91.93 & $4.67 \pm 0.08$ \\
\hline $49-70 \mathrm{~cm}$ & 1.06 & $1.91 \pm 0.06$ & $0.43 \pm 0.01$ & $24.46 \pm 0.09$ & $0.21 \pm 3.03$ & $0.05 \pm 0.68$ & $4.77 \pm 69.05$ & 0.11 & $7.81 \pm 0.02$ & $\mathrm{bdl} \pm \mathrm{bdl}$ & 4.38 & $0.94 \pm 0.01$ \\
\hline $70-90 \mathrm{~cm}$ & 0.98 & $6.61 \pm 0.05$ & $1.30 \pm 0.01$ & $32.53 \pm 1.81$ & $3.26 \pm 4.52$ & $0.64 \pm 0.89$ & $15.72 \pm 21.79$ & 0.49 & $20.31 \pm 1.13$ & $\mathrm{bdl} \pm \mathrm{bdl}$ & 20.73 & $1.41 \pm 0.07$ \\
\hline Total & & $53.56 \pm 6.42$ & $5.02 \pm 0.22$ & $65.78 \pm 3.64$ & $51.44 \pm 8.44$ & $3.30 \pm 1.64$ & $9.78 \pm 1.60$ & & $81.42 \pm 4.36$ & $0.12 \pm 0.01$ & 525.76 & $21.69 \pm 0.37$ \\
\hline \multicolumn{13}{|c|}{ Medium 1 (50-300 a) } \\
\hline $0-9 \mathrm{~cm}$ & 0.06 & $11.16 \pm 0.25$ & $0.06 \pm 0.00$ & $98.32 \pm 4.44$ & $30.24 \pm 0.28$ & $0.17 \pm 0.00$ & $7.28 \pm 0.07$ & 2.71 & $11.35 \pm 0.25$ & $0.06 \pm 0.01$ & 415.30 & $17.85 \pm 0.26$ \\
\hline $9-15 \mathrm{~cm}$ & 0.13 & $21.89 \pm 0.14$ & $0.17 \pm 0.00$ & $123.61 \pm 15.20$ & $38.55 \pm 2.60$ & $0.31 \pm 0.02$ & $8.84 \pm 0.60$ & 1.76 & $17.71 \pm 2.07$ & $0.17 \pm 0.02$ & 436.30 & $15.50 \pm 1.40$ \\
\hline $15-48 \mathrm{~cm}$ & 0.58 & $12.25 \pm 0.37$ & $2.33 \pm 0.07$ & $42.90 \pm 3.04$ & $21.10 \pm 8.78$ & $4.02 \pm 1.67$ & $28.48 \pm 11.85$ & 1.72 & $28.57 \pm 1.16$ & $0.10 \pm 0.06$ & 74.10 & $6.01 \pm 0.82$ \\
\hline $48-73 \mathrm{~cm}$ & 1.15 & $4.92 \pm 0.40$ & $1.42 \pm 0.11$ & $30.75 \pm 4.70$ & $9.93 \pm 0.48$ & $2.86 \pm 0.14$ & $26.20 \pm 1.25$ & 2.02 & $15.99 \pm 1.15$ & $0.01 \pm 0.00$ & 37.90 & $1.33 \pm 0.07$ \\
\hline $73-89 \mathrm{~cm}$ & 0.36 & $9.31 \pm 0.12$ & $0.54 \pm 0.01$ & $35.78 \pm 2.47$ & $26.84 \pm 0.84$ & $1.56 \pm 0.05$ & $42.41 \pm 1.32$ & 2.88 & $26.03 \pm 1.47$ & $0.04 \pm 0.01$ & 63.30 & $3.12 \pm 0.17$ \\
\hline $89-123 \mathrm{~cm}$ & 0.53 & $7.63 \pm 1.02$ & $1.37 \pm 0.18$ & $30.94 \pm 4.51$ & $3.81 \pm 0.95$ & $0.68 \pm 0.17$ & $39.31 \pm 9.78$ & 0.50 & $24.67 \pm 0.30$ & $\mathrm{bdl} \pm \mathrm{bdl}$ & 9.70 & $0.69 \pm 0.12$ \\
\hline Total & & $67.18 \pm 2.29$ & $5.90 \pm 0.38$ & $54.03 \pm 2.71$ & $130.48 \pm 13.93$ & $9.61 \pm 2.05$ & $12.59 \pm 1.34$ & & $124.33 \pm 6.15$ & $0.38 \pm 0.10$ & 1036.60 & $44.48 \pm 2.83$ \\
\hline \multicolumn{13}{|c|}{ Medium 2 (50-300 a) } \\
\hline $0-12 \mathrm{~cm}$ & 0.13 & $28.18 \pm 5.84$ & $0.45 \pm 0.09$ & $100.10 \pm 2.57$ & $45.44 \pm 8.23$ & $0.73 \pm 0.13$ & $10.99 \pm 1.99$ & 1.61 & $28.15 \pm 0.67$ & $0.10 \pm 0.02$ & 413.52 & $0.85 \pm 0.09$ \\
\hline $12-14 \mathrm{~cm}$ & 0.27 & $13.71 \pm 0.49$ & $0.07 \pm 0.00$ & $82.49 \pm 9.08$ & $36.13 \pm 7.98$ & $0.20 \pm 0.04$ & $11.12 \pm 2.46$ & 2.64 & $16.62 \pm 1.82$ & $0.12 \pm 0.00$ & 324.82 & $0.74 \pm 0.08$ \\
\hline $14-40 \mathrm{~cm}$ & 0.66 & $10.34 \pm 0.15$ & $1.78 \pm 0.03$ & $36.23 \pm 0.20$ & $20.40 \pm 5.24$ & $3.51 \pm 0.90$ & $19.71 \pm 5.06$ & 1.97 & $28.53 \pm 0.14$ & $0.11 \pm 0.00$ & 103.54 & $0.27 \pm 0.00$ \\
\hline $40-80 \mathrm{~cm}$ & 0.60 & $10.02 \pm 0.66$ & $2.40 \pm 0.16$ & $38.91 \pm 1.24$ & $18.86 \pm 8.60$ & $4.51 \pm 2.06$ & $19.26 \pm 8.78$ & 1.88 & $25.76 \pm 0.78$ & $0.06 \pm 0.01$ & 97.93 & $0.24 \pm 0.01$ \\
\hline $80-126 \mathrm{~cm}$ & 0.67 & $7.38 \pm 0.06$ & $2.27 \pm 0.02$ & $39.81 \pm 2.24$ & $4.92 \pm 0.82$ & $1.51 \pm 0.25$ & $16.24 \pm 2.72$ & 0.67 & $18.54 \pm 1.04$ & $\mathrm{bdl} \pm \mathrm{bdl}$ & 30.32 & $0.06 \pm 0.01$ \\
\hline Total & & $69.63 \pm 7.20$ & $6.97 \pm 0.30$ & $59.21 \pm 2.34$ & $125.75 \pm 30.86$ & $10.46 \pm 3.39$ & $12.96 \pm 3.18$ & & $117.61 \pm 4.45$ & $0.40 \pm 0.03$ & 970.13 & $2.16 \pm 0.19$ \\
\hline
\end{tabular}




\begin{tabular}{|c|c|c|c|c|c|c|c|c|c|c|c|c|}
\hline & $\begin{array}{c}\text { Bulk } \\
\text { density }\end{array}$ & $\begin{array}{c}\text { Reactive Fe } \\
\text { (control corrected) }\end{array}$ & $\begin{array}{l}\text { Reactive Fe stock } \\
\text { (control corrected) }\end{array}$ & $\begin{array}{l}\text { Relative amount } \\
\text { reactive Fe }\end{array}$ & $\begin{array}{l}\text { Fe-associated OC } \\
\text { (control corrected) }\end{array}$ & $\begin{array}{l}\begin{array}{l}\text { Fe-associated OC stock } \\
\text { (control corrected) }\end{array}\end{array}$ & $\begin{array}{c}\text { Relative amount } \\
\text { Fe-associated OC }\end{array}$ & $\begin{array}{c}\text { OC:Fe } \\
\text { ratio }\end{array}$ & Total $\mathrm{Fe}$ & Control Fe & "TOC & Control OC \\
\hline & $\mathrm{g} \mathrm{cm}^{-3}$ & $\mathrm{mg} \mathrm{g}^{-1}$ & $\mathrm{~kg} \mathrm{~m}^{-2}$ & $\%$ of tot. Fe & $\mathrm{mg} \mathrm{g}^{-1}$ & $\mathrm{~kg} \mathrm{~m}^{-2}$ & $\%$ of TOC & & $\mathrm{mg} \mathrm{g}^{-1}$ & $\mathrm{mg} \mathrm{g}^{-1}$ & $\mathrm{mg} \mathrm{g}^{-1}$ & $\mathrm{mg} \mathrm{g}^{-1}$ \\
\hline \multicolumn{13}{|c|}{ Old 1 (300-2000 a) } \\
\hline $0-12 \mathrm{~cm}$ & 0.33 & $24.87 \pm 0.86$ & $0.98 \pm 0.03$ & $106.43 \pm 4.11$ & $46.82 \pm 4.60$ & $1.85 \pm 0.18$ & $11.01 \pm 1.08$ & 1.88 & $23.37 \pm 0.10$ & $0.41 \pm 0.00$ & 425.40 & $13.14 \pm 0.37$ \\
\hline $12-32 \mathrm{~cm}$ & 1.14 & $9.65 \pm 0.15$ & $2.20 \pm 0.03$ & $49.24 \pm 4.44$ & $8.94 \pm 1.92$ & $2.04 \pm 0.44$ & $23.03 \pm 4.95$ & 0.93 & $19.59 \pm 1.47$ & $0.30 \pm 0.11$ & 38.80 & $1.76 \pm 0.22$ \\
\hline $32-57 \mathrm{~cm}$ & 0.50 & $10.75 \pm 0.03$ & $1.36 \pm 0.00$ & $48.39 \pm 1.32$ & $7.04 \pm 3.94$ & $0.89 \pm 0.50$ & $5.19 \pm 2.90$ & 0.66 & $22.21 \pm 0.55$ & $0.21 \pm 0.00$ & 135.60 & $3.10 \pm 0.30$ \\
\hline $57-85 \mathrm{~cm}$ & 0.61 & $10.13 \pm 0.33$ & $1.72 \pm 0.06$ & $46.34 \pm 2.38$ & $2.46 \pm 0.24$ & $0.42 \pm 0.04$ & $7.18 \pm 0.69$ & 0.24 & $21.86 \pm 0.40$ & $0.18 \pm 0.01$ & 34.20 & $1.93 \pm 0.12$ \\
\hline $85-105 \mathrm{~cm}$ & 0.99 & $8.96 \pm 0.19$ & $1.77 \pm 0.04$ & $51.05 \pm 1.33$ & $7.68 \pm 2.38$ & $1.52 \pm 0.47$ & $18.91 \pm 5.86$ & 0.86 & $17.56 \pm 0.09$ & $0.18 \pm 0.00$ & 40.60 & $1.67 \pm 0.01$ \\
\hline Total & & $64.36 \pm 1.55$ & $8.03 \pm 0.16$ & $61.54 \pm 1.56$ & $72.94 \pm 13.08$ & $6.71 \pm 1.63$ & $10.81 \pm 1.94$ & & $104.58 \pm 2.61$ & $1.28 \pm 0.12$ & 674.60 & $21.61 \pm 1.01$ \\
\hline \multicolumn{13}{|c|}{ Old 2 (300-2000 a) } \\
\hline $0-8 \mathrm{~cm}$ & 0.13 & $19.45 \pm 1.18$ & $0.20 \pm 0.01$ & $144.36 \pm 30.09$ & $19.69 \pm 8.37$ & $0.20 \pm 0.08$ & $5.95 \pm 2.53$ & 1.01 & $13.47 \pm 2.80$ & $0.10 \pm 0.01$ & 331.00 & $14.68 \pm 1.55$ \\
\hline $8-15 \mathrm{~cm}$ & 0.11 & $15.77 \pm 0.38$ & $0.12 \pm 0.00$ & $105.11 \pm 5.23$ & $20.95 \pm 5.71$ & $0.16 \pm 0.04$ & $4.88 \pm 1.33$ & 1.33 & $15.01 \pm 0.74$ & $0.22 \pm 0.00$ & 429.15 & $13.57 \pm 0.52$ \\
\hline $15-37 \mathrm{~cm}$ & 0.39 & $12.78 \pm 1.20$ & $1.08 \pm 0.10$ & $56.85 \pm 1.22$ & $25.75 \pm 2.94$ & $2.18 \pm 0.25$ & $11.91 \pm 1.36$ & 2.02 & $22.48 \pm 0.45$ & $0.12 \pm 0.03$ & 216.24 & $10.01 \pm 1.94$ \\
\hline $37-68 \mathrm{~cm}$ & 0.08 & $5.99 \pm 0.12$ & $0.15 \pm 0.00$ & $25.67 \pm 0.04$ & $9.16 \pm 0.89$ & $0.23 \pm 0.02$ & $6.37 \pm 0.62$ & 1.53 & $23.33 \pm 0.01$ & $0.05 \pm 0.00$ & 143.88 & $4.84 \pm 0.05$ \\
\hline $68-108 \mathrm{~cm}$ & 0.65 & $8.04 \pm 0.07$ & $2.10 \pm 0.02$ & $32.13 \pm 0.51$ & $3.65 \pm 2.94$ & $0.95 \pm 0.77$ & $4.08 \pm 3.29$ & 0.45 & $25.03 \pm 0.39$ & $0.06 \pm 0.00$ & 89.34 & $4.17 \pm 0.28$ \\
\hline $108-114 \mathrm{~cm}$ & 1.45 & $7.97 \pm 0.09$ & $0.69 \pm 0.01$ & $34.64 \pm 0.58$ & $3.84 \pm 6.37$ & $0.33 \pm 0.55$ & $6.55 \pm 10.88$ & 0.48 & $23.02 \pm 0.38$ & $\mathrm{bdl} \pm \mathrm{bdl}$ & 58.57 & $2.25 \pm 0.06$ \\
\hline Total & & $70.00 \pm \mathbf{3 . 0 4}$ & $4.34 \pm 0.14$ & $57.22 \pm 2.28$ & $83.04 \pm 27.23$ & $4.05 \pm 1.72$ & $6.86 \pm 2.25$ & & $122.33 \pm 4.78$ & $0.55 \pm 0.06$ & 1268.18 & $49.53 \pm 4.40$ \\
\hline \multicolumn{13}{|c|}{ Ancient 1 (2000-5500 a) } \\
\hline $0-7 \mathrm{~cm}$ & 0.17 & $60.26 \pm 2.09$ & $0.74 \pm 0.03$ & $136.85 \pm 13.28$ & $34.65 \pm 0.33$ & $0.42 \pm 0.00$ & $11.26 \pm 0.11$ & 0.57 & $44.03 \pm 2.75$ & $0.04 \pm 0.01$ & 307.70 & $22.70 \pm 0.05$ \\
\hline $7-17 \mathrm{~cm}$ & 0.14 & $32.88 \pm 1.61$ & $0.45 \pm 0.02$ & $99.65 \pm 11.00$ & $42.38 \pm 4.75$ & $0.58 \pm 0.06$ & $12.02 \pm 1.35$ & 1.29 & $33.00 \pm 2.02$ & $0.31 \pm 0.02$ & 352.50 & $20.02 \pm 0.35$ \\
\hline $17-34 \mathrm{~cm}$ & 1.12 & $2.63 \pm 0.66$ & $0.50 \pm 0.12$ & $17.15 \pm 4.31$ & $4.36 \pm 4.76$ & $0.83 \pm 0.90$ & $14.74 \pm 16.07$ & 1.66 & $15.36 \pm 0.03$ & $0.02 \pm 0.00$ & 29.60 & $3.81 \pm 0.12$ \\
\hline $34-50 \mathrm{~cm}$ & 0.60 & $21.82 \pm 1.05$ & $2.08 \pm 0.10$ & $89.94 \pm 12.80$ & $39.24 \pm 5.14$ & $3.75 \pm 0.49$ & $41.13 \pm 5.39$ & 1.80 & $24.26 \pm 2.28$ & $0.11 \pm 0.05$ & 95.40 & $8.81 \pm 1.93$ \\
\hline $50-87 \mathrm{~cm}$ & 0.45 & $15.33 \pm 0.88$ & $2.53 \pm 0.15$ & $51.54 \pm 8.74$ & $13.62 \pm 3.37$ & $2.25 \pm 0.56$ & $12.09 \pm 2.99$ & 0.89 & $29.75 \pm 3.34$ & $0.02 \pm 0.00$ & 112.60 & $5.72 \pm 0.06$ \\
\hline $87-116 \mathrm{~cm}$ & 0.66 & $7.62 \pm 0.06$ & $1.45 \pm 0.01$ & $32.88 \pm 0.53$ & bdl \pm bdl & bdl \pm bdl & $\mathrm{bdl} \pm \mathrm{bdl}$ & bdl & $23.19 \pm 0.18$ & $0.00 \pm 0.00$ & 22.90 & $3.04 \pm 0.29$ \\
\hline Total & & $140.55 \pm 6.36$ & $7.76 \pm 0.43$ & $82.88 \pm 3.88$ & $134.25 \pm 18.34$ & $7.83 \pm 2.02$ & $14.58 \pm 1.99$ & & $169.59 \pm 7.84$ & $0.50 \pm 0.08$ & 920.70 & $64.11 \pm 2.80$ \\
\hline \multicolumn{13}{|c|}{ Ancient 2 (2000-5500 a) } \\
\hline $0-7 \mathrm{~cm}$ & 0.35 & $17.72 \pm 0.61$ & $0.50 \pm 0.02$ & $77.12 \pm 3.97$ & $31.68 \pm 6.05$ & $0.90 \pm 0.17$ & $7.77 \pm 1.48$ & 1.79 & $22.97 \pm 1.17$ & $0.07 \pm 0.00$ & 407.85 & $12.09 \pm 0.64$ \\
\hline $7-17 \mathrm{~cm}$ & 0.52 & $15.33 \pm 1.01$ & $0.72 \pm 0.05$ & $105.89 \pm 1.13$ & $77.50 \pm 8.62$ & $3.63 \pm 0.40$ & $17.57 \pm 1.95$ & 5.05 & $14.48 \pm 0.14$ & $0.14 \pm 0.01$ & 441.09 & $16.77 \pm 0.13$ \\
\hline $17-34 \mathrm{~cm}$ & 0.61 & $4.59 \pm 0.10$ & $0.51 \pm 0.01$ & $38.98 \pm 4.25$ & $21.70 \pm 10.08$ & $2.39 \pm 1.11$ & $16.28 \pm 7.56$ & 4.72 & $11.78 \pm 1.28$ & $0.03 \pm 0.00$ & 133.30 & $5.45 \pm 0.35$ \\
\hline $34-50 \mathrm{~cm}$ & 0.32 & $8.33 \pm 0.77$ & $0.85 \pm 0.08$ & $38.59 \pm 1.71$ & bdl \pm bdl & $\mathrm{bdl} \pm \mathrm{bdl}$ & $\mathrm{bdl} \pm \mathrm{bdl}$ & bdl & $21.59 \pm 0.91$ & $0.03 \pm 0.02$ & 67.93 & $3.49 \pm 0.15$ \\
\hline $50-87 \mathrm{~cm}$ & 0.57 & $6.56 \pm 0.24$ & $1.16 \pm 0.04$ & $38.51 \pm 1.05$ & $3.20 \pm 1.36$ & $0.57 \pm 0.24$ & $7.02 \pm 2.98$ & 0.49 & $17.04 \pm 0.45$ & $\mathrm{bdl} \pm \mathrm{bdl}$ & 45.60 & $3.47 \pm 0.05$ \\
\hline $87-116 \mathrm{~cm}$ & 0.99 & $5.25 \pm 0.02$ & $1.30 \pm 0.01$ & $44.40 \pm 3.26$ & $10.16 \pm 3.59$ & $2.53 \pm 0.89$ & $51.01 \pm 18.03$ & 1.94 & $11.83 \pm 0.87$ & $\mathrm{bdl} \pm \mathrm{bdl}$ & 19.92 & $2.99 \pm 0.05$ \\
\hline Total & & $57.79 \pm 2.75$ & $5.04 \pm 0.20$ & $57.97 \pm 2.85$ & $144.25 \pm 29.70$ & $10.01 \pm 2.82$ & $12.93 \pm 2.66$ & & $99.69 \pm 4.82$ & $0.27 \pm 0.02$ & 1115.70 & $44.26 \pm 1.35$ \\
\hline
\end{tabular}


Supplementary methods

Table SI 4 | Mössbauer spectra hyperfine parameters for organic, cryoturbated and mineral horizons of young and ancient soil cores along a permafrost soil chronosequence of drained thaw lake basins from Alaska.

\begin{tabular}{|c|c|c|c|c|c|c|c|c|c|}
\hline Sample & Temperature & Phase & CS & $\Delta \mathbf{E}_{\mathbf{Q}}$ & $\varepsilon$ & $B_{h f}$ & Pop ( \pm ) & $\chi^{2}$ & Fe mineral phase \\
\hline & $\mathrm{K}$ & & $\mathrm{mm} \mathrm{s}^{-1}$ & $\mathrm{~mm} \mathrm{~s}^{-1}$ & $\mathrm{~mm} \mathrm{~s}^{-1}$ & $\mathrm{~T}$ & $\%$ & & \\
\hline \multirow{3}{*}{$\begin{array}{l}\text { Young } 1 \text { - } \\
\text { organic }\end{array}$} & 77 & Db1 & 0.42 & 0.73 & & & $100(0.32)$ & 0.57 & $\mathrm{Fe}(\mathrm{III}), \mathrm{Fh}$ \\
\hline & 5 & Sxt & 0.44 & & -0.02 & 45.5 & $88(0.31)$ & 0.6 & $\mathrm{Fe}(\mathrm{III}), \mathrm{Fh}$ \\
\hline & & $\mathrm{Db}$ & 0.54 & 0.84 & & & $11(0.57)$ & & - \\
\hline \multirow{4}{*}{$\begin{array}{c}\text { Young } 2 \text { - } \\
\text { cryoturbated }\end{array}$} & 77 & Dbl & 0.47 & 0.68 & & & $58.1(0.27)$ & 0.69 & $\mathrm{Fe}(\mathrm{III}), \mathrm{Fh}$ \\
\hline & & $\mathrm{Db} 2$ & 1.24 & 2.88 & & & $41.9(0.27)$ & & $\mathrm{Fe}(\mathrm{II})$ \\
\hline & 5 & Sxt1 & 0.45 & & -0.05 & 47.4 & $26.0(0.26)$ & 1.01 & $\mathrm{Fe}(\mathrm{III}), \mathrm{Fh}$ \\
\hline & & Sxt2 & 0.93 & & 0.38 & 7.75 & $74.0(0.41)$ & & - \\
\hline \multirow{4}{*}{$\begin{array}{l}\text { Young } 1 \text { - } \\
\text { mineral }\end{array}$} & 77 & $\mathrm{Db} 1$ & 0.47 & 0.69 & & & $57.9(0.29)$ & 0.62 & $\mathrm{Fe}(\mathrm{III}), \mathrm{Fh}$ \\
\hline & & $\mathrm{Db} 2$ & 1.24 & 2.86 & & & $42.1(0.20)$ & & $\mathrm{Fe}(\mathrm{II})$ \\
\hline & 5 & Sxt1 & 0.42 & & -0.08 & 48.7 & $28.3(0.49)$ & 0.77 & $\mathrm{Fe}(\mathrm{IIII}), \mathrm{Fh}$ \\
\hline & & Sxt2 & 0.92 & & 0.43 & 7.55 & $71.7(0.49)$ & & - \\
\hline \multirow{3}{*}{$\begin{array}{l}\text { Ancient } 1 \text { - } \\
\text { organic }\end{array}$} & 77 & $\mathrm{Db} 1$ & 0.49 & 0.77 & & & $100(0.14)$ & 0.59 & $\mathrm{Fe}(\mathrm{III}), \mathrm{Fh}$ \\
\hline & 5 & Sxt & 0.47 & & -0.05 & 47.8 & $69.4(0.48)$ & 0.66 & $\mathrm{Fe}(\mathrm{III}), \mathrm{Fh}$ \\
\hline & & $\mathrm{Db}$ & 0.48 & 0.53 & & & $30.6(0.42)$ & & - \\
\hline \multirow{4}{*}{$\begin{array}{l}\text { Ancient } 1 \text { - } \\
\text { cryoturbated }\end{array}$} & 77 & Db1 & 0.43 & 0.75 & & & $54.3(0.42)$ & 0.59 & $\mathrm{Fe}(\mathrm{IIII}), \mathrm{Fh}$ \\
\hline & & $\mathrm{Db} 2$ & 1.2 & 2.71 & & & $45.7(0.40)$ & & $\mathrm{Fe}(\mathrm{II})$ \\
\hline & 5 & Sxt1 & 0.43 & & -0.06 & 47.46 & $33.3(0.49)$ & 0.67 & $\mathrm{Fe}(\mathrm{III}), \mathrm{Fh}$ \\
\hline & & Sxt2 & 0.87 & & 0.44 & 7.84 & $66.6(0.55)$ & & - \\
\hline \multirow{4}{*}{$\begin{array}{c}\text { Ancient } 1 \text { - } \\
\text { mineral }\end{array}$} & 77 & $\mathrm{Db} 1$ & 0.49 & 0.71 & & & $42.9(0.34)$ & 0.67 & $\mathrm{Fe}(\mathrm{III}), \mathrm{Fh}$ \\
\hline & & $\mathrm{Db} 2$ & 1.21 & 2.7 & & & $57.1(0.19)$ & & $\mathrm{Fe}(\mathrm{II})$ \\
\hline & 5 & Sxt1 & 0.45 & & -0.05 & 47.35 & $28.4(0.31)$ & 1.15 & $\mathrm{Fe}(\mathrm{III}), \mathrm{Fh}$ \\
\hline & & Sxt2 & 0.91 & & 0.39 & 7.72 & $71.6(0.21)$ & & - \\
\hline
\end{tabular}

Db: doublet, Sxt: sextet, CS: center shift, $\triangle \mathrm{EQ}$ : quadrupole splitting, $\varepsilon$ : quadrupole shift, $\mathrm{B}_{\mathrm{hf}}$ hyperfine field, Pop: relative abundance, $\chi 2$ : goodness of fit, Fe mineral phase - Fe(II): ferrous Fe, Fe(III): ferric Fe, Fh: ferrihydrite, - : unknown 
(a)

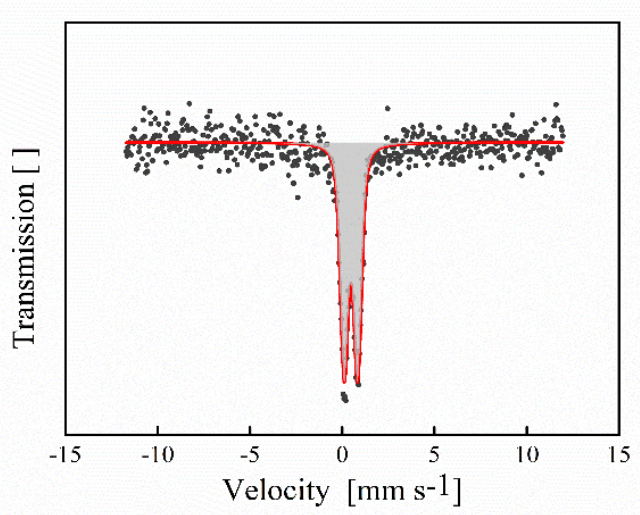

(c)

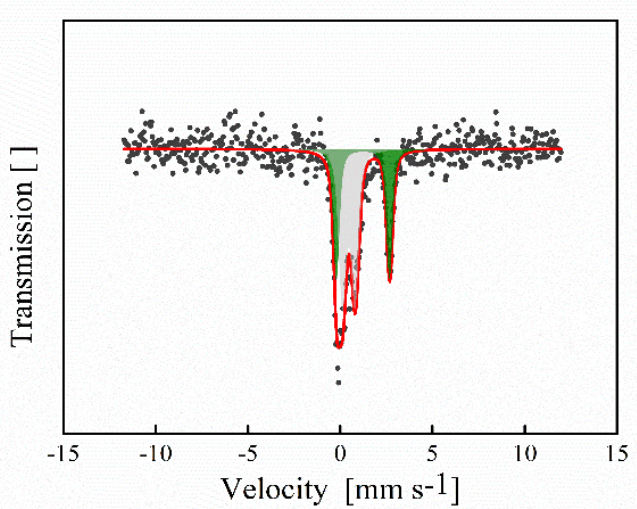

(e)

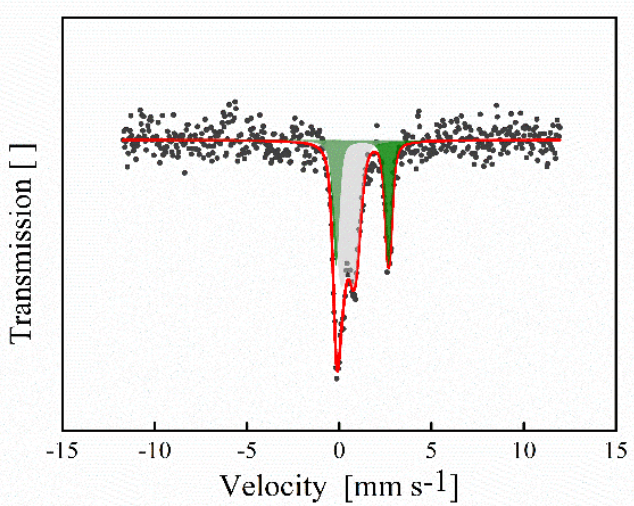

(b)

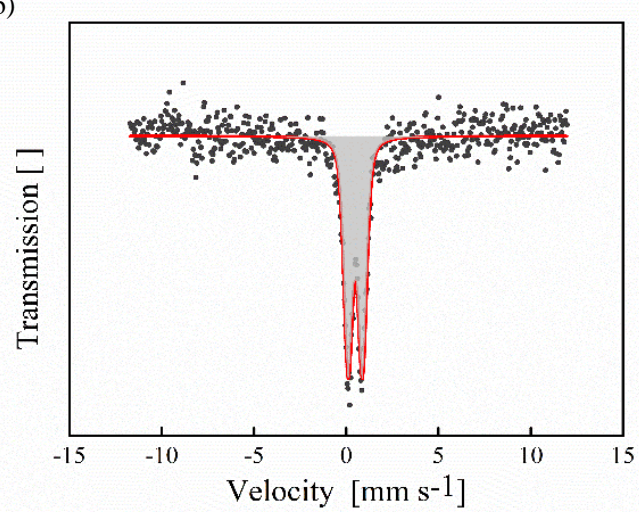

(d)

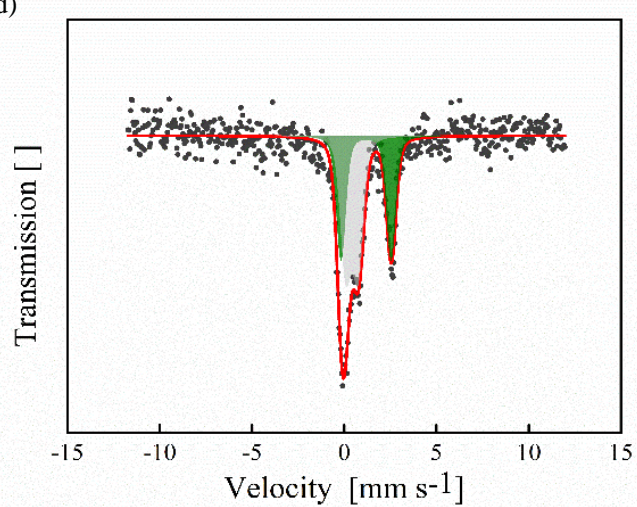

(f)

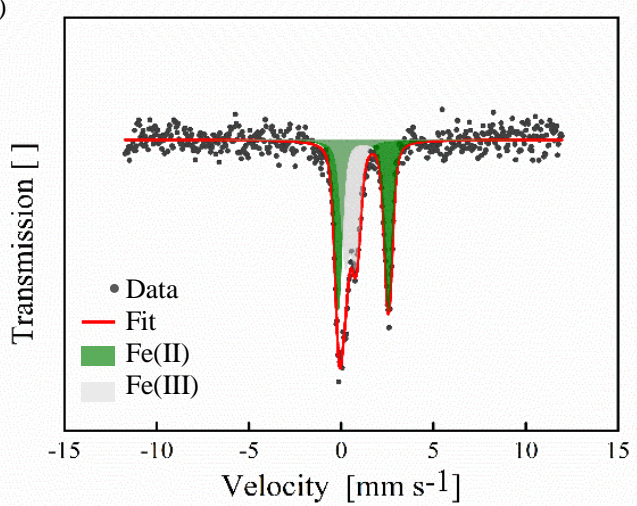

Figure SI 5 | Mössbauer transmission spectra collected at $77 \mathrm{~K}$ for (a) Young 1 - organic, (b) Ancient 1 - organic, (c) Young 2 - cryoturbated, (d) Ancient 1 - cryoturbated, (e) Young 1 mineral and $(f)$ Ancient 1 - mineral horizons of young and ancient soil cores along a permafrost soil chronosequence in northern Alaska. 
(a)

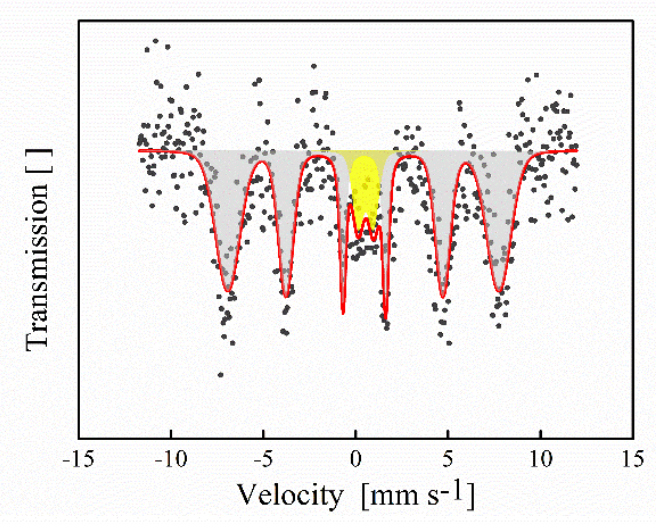

(c)

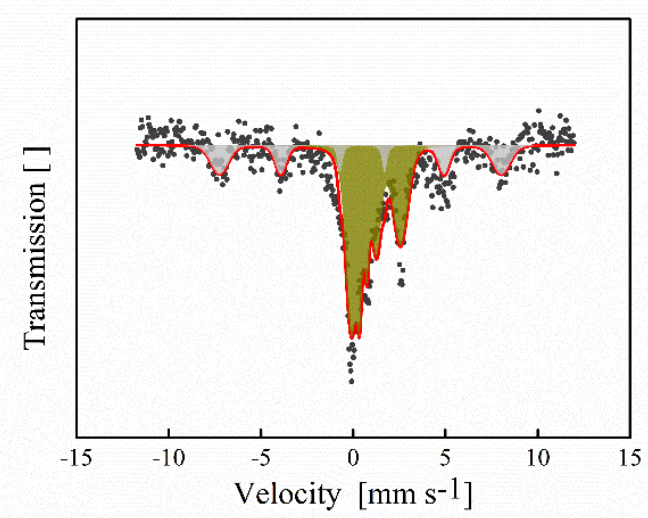

(e)

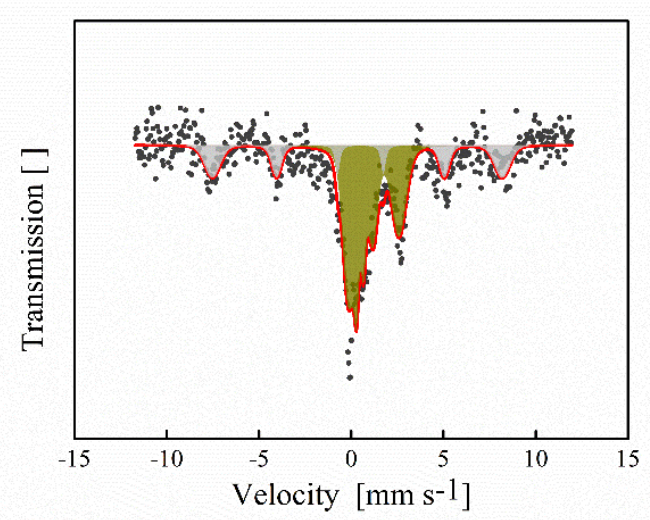

(b)

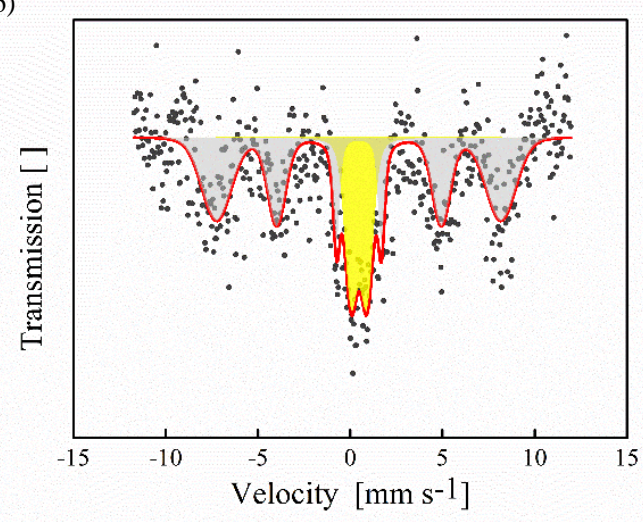

(d)

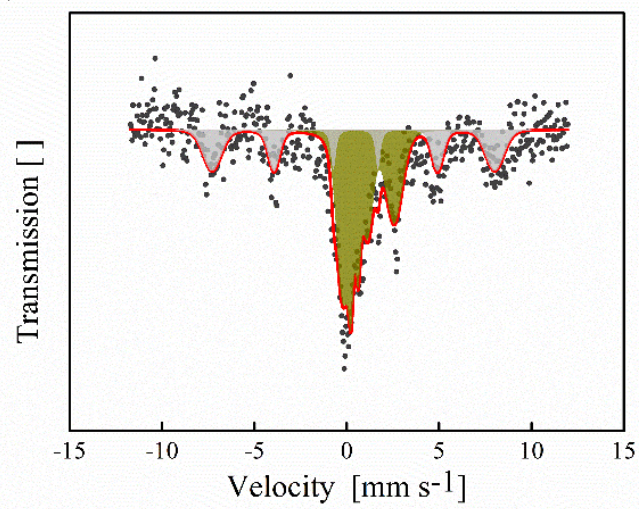

(f)

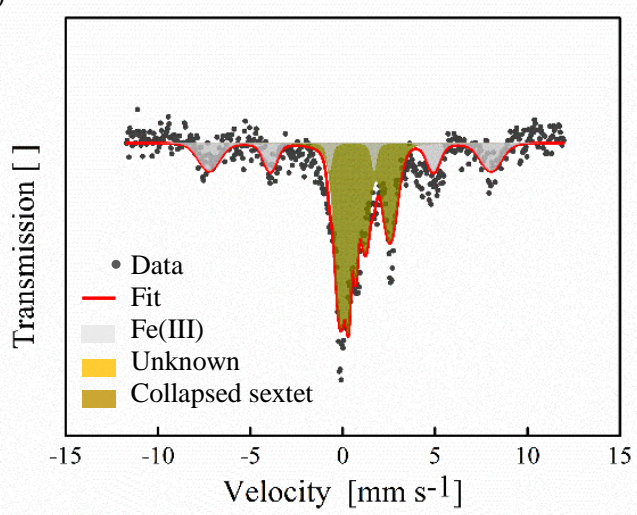

Figure SI 6 | Mössbauer transmission spectra collected at 5 K for (a) Young 1 - organic, (b) Ancient 1 - organic, (c) Young 2 - cryoturbated, (d) Ancient 1 - cryoturbated, (e) Young 1 mineral and $(f)$ Ancient 1 - mineral horizons of young and ancient soil cores along a permafrost soil chronosequence in northern Alaska. 